University of Wollongong

Research Online

Faculty of Science, Medicine and Health -

Papers: part A

Faculty of Science, Medicine and Health

2017

\title{
The geoarchaeology of hominin dispersals to and from tropical Southeast Asia: A review and prognosis
}

Mike W. Morley

University of Wollongong, mmorley@uow.edu.au

Follow this and additional works at: https://ro.uow.edu.au/smhpapers

Part of the Medicine and Health Sciences Commons, and the Social and Behavioral Sciences

Commons

\section{Recommended Citation}

Morley, Mike W., "The geoarchaeology of hominin dispersals to and from tropical Southeast Asia: A review and prognosis" (2017). Faculty of Science, Medicine and Health - Papers: part A. 4470.

https://ro.uow.edu.au/smhpapers/4470

Research Online is the open access institutional repository for the University of Wollongong. For further information contact the UOW Library: research-pubs@uow.edu.au 


\title{
The geoarchaeology of hominin dispersals to and from tropical Southeast Asia: A review and prognosis
}

\author{
Abstract \\ Tropical Southeast Asia is a critically important region for addressing the major questions and grand \\ challenges that concern us today regarding Late Pleistocene hominin dispersals across the Old World. \\ Geoarchaeological science is widely employed in many regions of the world to contextualise \\ archaeological material and provide an environmental backdrop against which to explore archaeological \\ narratives. However, in Southeast Asia there is an apparent lag in the routine use of this Earth-Science \\ approach despite the abundance of archaeological sites important in explicating past hominin dispersals \\ to and from the region. In this review of the state-of-the-art of geoarchaeological research in Southeast \\ Asia, I examine the role of the discipline in addressing the important issues in archaeology today. I \\ identify where geoarchaeology is being used and to what effect, highlighting gaps in the \\ geoarchaeological dataset. From a methodological point of view it is imperative that archaeologists and \\ geoarchaeologists working in Southeast Asia (and other humid tropical regions of the world) fully \\ appreciate how to interpret the geoarchaeological signatures associated with this climate regime so that \\ methods and practice can be refined. A series of steps that will serve to drive forward geoarchaeological \\ research in the region are also proposed.

\section{Disciplines} \\ Medicine and Health Sciences | Social and Behavioral Sciences

\section{Publication Details} \\ Morley, M. W. (2017). The geoarchaeology of hominin dispersals to and from tropical Southeast Asia: A \\ review and prognosis. Journal of Archaeological Science, 77 78-93.
}


The Geoarchaeology of Hominin Dispersals to and from Tropical Southeast Asia: A Review and Prognosis for the Future

Mike W Morley

Centre for Archaeological Science (CAS), University of Wollongong, Northfields Avenue, Wollongong, NSW, 2500, Australia.

\begin{abstract}
Tropical Southeast Asia is a critically important region for addressing major questions and grand challenges concerning the evolution and spread of hominins across the Old World. Despite the youth of the discipline, geoarchaeology is widely employed as an integral part of archaeological investigation in many regions of the world (e.g. Western Europe, South Africa, North America). In Southeast Asia, however, there is an apparent lag in this process despite the abundance of archaeological sites important in explicating topics concerning past hominin dispersals to and from the region. In this review of the state-of-the-art of geoarchaeological research in Southeast Asia, I examine the role of the discipline in addressing the important issues in archaeology today. I identify where geoarchaeology is being used and to what effect, highlighting gaps in the geoarchaeological dataset, and outlining the archaeological research agendas that would benefit from adopting an Earth Science-approach. Given that a significant area of the region falls under Köppen's 'Tropical/Megathermal' climate classification, from a methodological point of view it is imperative that geoarchaeologists working in Southeast Asia (and other humid tropical regions of the world) fully appreciate how to interpret the geoarchaeological signatures associated with this climate regime so that methods and practice can be refined. Finally, I suggest a series of steps that might be taken to drive forward geoarchaeological research in the region.
\end{abstract}

\title{
1. What is geoarchaeology and how does an earth science approach enhance interpretation of the archaeological record of modern human colonisation of Southeast Asia?
}

The dispersal of Homo sapiens out of Africa and across Asia and into Australia during the Upper Pleistocene (MIS 5-2) is a topic currently experiencing a surge of research interest (Dennell, 2008, 2015a; Dennell and Petraglia, 2012; Boivin et al., 2013; Dennell and Porr, 2013; Groucutt et al., 2015; Hiscock, 2015; O'Connor, 2015). The number of dated $H$. sapiens sites outside Africa is growing, and allied with considerable advances in scientific techniques such as palaeogenetics, and the growing awareness that Upper Pleistocene hominin demographics were likely inordinately complex, Southeast Asia is currently a hotspot of human evolutionary research. It is likely that we will witness in the next decade an unprecedented explosion in archaeological research in the region, as the timing, mechanisms and routes of these dispersal events are further constrained. 
Geoarchaeology is a discipline that borrows concepts and techniques from a broad range of Earth Sciences, including geology, geomorphology and sedimentology, to bring to bear on archaeological questions (Woodward and Goldberg, 2001; Goldberg and Macphail, 2008). For the purposes of this review I summarise geoarchaeology as having three main aims: i) to understand the processes of archaeological site formation, preservation and destruction; ii) to assess the integrity of archaeological stratigraphy and reconstruct the depositional and post-depositional histories that have formed these sediments; iii) to situate humans (and hominins) within the dynamics of the Quaternary landscape, and to elucidate the nature, degree and directionality of humanenvironment interactions.

Despite the wealth of Upper Pleistocene archaeology in Southeast Asia (e.g. Anderson, 1997; Barker, 2013, 2016; Aubert et al., 2014; Bellwood, 2014; Higham, 2014; Sutikna et al., 2016; van den Bergh et al., 2016), geoarchaeology has to date played a disappointingly minor role (but see Anderson, 1997; Lewis 2003, 2007; Stephens et al., 2005; Mijares and Lewis, 2009; Westaway 2009b). This is in contrast to its regular application across many non-tropical regions (e.g. Western Europe, Southern Africa, North America). The reasons for this are complex and multifarious, most likely reflecting the history of archaeological research in a particular country (often a function of its colonial past), economic and geopolitical context, ease of fieldwork and accessibility of sites, and a lack of local specialists. This dearth of geoarchaeological data precludes a thorough understanding of exactly how tropical geomorphological processes form, modify and preserve archaeological sites and sediments in these environments. The tropics can be challenging environments in which to conduct archaeological research, not least because baseline environmental conditions are not conducive to the preservation of archaeological material (e.g. Barker et al., 2005;

Kourampas et al., 2009; Mijares and Lewis, 2009). This is especially pertinent for organic elements such as bones, wood, ancient DNA and other biomarkers, as well as mobile minerals such as calcium carbonate (Weiner, 2010). This situation can lead to a shortage of taxonomically-specific hominin fossils, which are particularly susceptible to chemical and physical degradation.

Notwithstanding that archaeologists often have an excellent appreciation of archaeological sediments and stratigraphy, geoarchaeologists have the expertise to model sediment delivery to a site, and to what extent-if any-post depositional processes modified or destroyed them. I will argue that regular dialogue must take place between practitioners of archaeology and geoarchaeology throughout all stages of the archaeological process. This is especially important as uncertainties clouding the provenance of important archaeological material can rarely be addressed as an afterthought. We are currently in a period of human evolutionary research where to find a single tooth, wrist bone or partial mandible holds the potential to re-write the history of our own species. Bearing this in mind, archaeologists must be absolutely certain of the stratigraphic context of a recovered skeletal element (Goldberg and Berna, 2010), and the environment of deposition in which is was deposited, and synergistic geoarchaeological research can greatly assist in this endeavour. 
Understanding modern human dispersals across Southeast Asia during the Upper Pleistocene is both challenging and exciting for two key reasons that are pertinent here. First, the physical geography of the region is such that any archaeological narrative has to be set against (and to some greater or lesser extent, is dictated by) the rise and fall of Quaternary sea levels repeatedly inundating and exposing the large tracts of continental shelf of Sunda and Sahul, between which lies the permanent islands of Wallacea, separated by deep, fastmoving currents (Allen and O'Connell, 2008; O'Connell et al., 2010; Dennell et al., 2014; O'Connor, 2015). Second, palaeoanthropological and palaeogenetic data show that this region (extending north into Southern China) has a complex demographic history involving a number of archaic and modern human "metapopulations" (Pääbo, 2014, 2015).

With this review it is my intention to explore the ways in which geoarchaeology can elucidate how, when, why and where humans first dispersed into and out of Southeast Asia. I will evaluate the geoarchaeological work that has been already undertaken in the region, seeking gaps in our knowledge, and areas in which geoarchaeology could usefully be employed. This will be followed by the presentation of a practical framework with which geoarchaeology might be promoted and utilised more effectively in the future, intended to provide a platform for discussion and collaboration between scientists working in the region.

\section{A very short introduction to the dispersal of Homo sapiens out of Africa and into Southeast Asia}

On the evidence currently available, Homo sapiens evolved in East Africa 200150 ka (e.g. White et al. 2003; McDougall et al. 2005), eventually expanding out of the continent during the Upper Pleistocene ( 125-14 ka; MIS 5-2). The exact timing, mechanism and environmental context of this dispersal remains poorly constrained due to the sparse and discontinuous datasets (both geographic and temporal) available outside Africa (Dennell and Porr, 2013). The consensus view for some time now has been that following an initial unsuccessful foray into Southwest Asia (The Levant), modern humans moved out of Africa in a single 'late' wave of dispersal, exploiting a riparian coastal route $\sim 60-50 \mathrm{ka}$ (Mellars 2006; Mellars et al. 2013). Recently, this view has been called into question, and there is now a groundswell of support for models favouring an earlier exit from Africa during the early Upper Pleistocene ( 120-100 ka) (e.g. Dennell and Petraglia, 2012; Boivin et al., 2013, Dennell and Porr, 2013; Groucutt et al., 2015; Reyes-Centeno et al., 2015; Hiscock, 2015). Given that the 100 ka modern human fossils from Skhul and Qafzeh in the Levant (e.g. Stringer, 1989) have long been the proverbial elephant in the room during these debates, regarded perhaps too easily as evidence for a failed colonisation event, a new earlier dispersal event (or events) may breathe new life into these fossils.

Despite growing acceptance of an earlier exit, this paradigm shift has until recently been based on tantalising hints rather than concrete evidence, often relying on interpretations of the stone tool record without demonstrable 
associations with modern human fossils (e.g. Armitage et al., 2011; Rose et al., 2011), or fossils from Southeast Asia and southern China that were either taxonomically ambiguous or beset with stratigraphic uncertainties (see Curnoe et al., 2012 and references therein). Recent research, however, appears to vindicate proponents of a late exit model. At Fuyan Cave, Southern China, a concentration of 'unequivocally' modern human teeth from a secure context (but see below) has been recovered, dated to 120-80 ka (Liu et al. 2015), fitting with the early exit model. These teeth in turn give credence to claims that fossils discovered at Zhirendong, also in southern China, are $100 \mathrm{ka}$ in age (Liu et al. 2010). There was some concern that these fossils belonged to an adapted form of H. erectus (Dennell, 2010), but these suspicions may now be allayed. Furthermore, a recent palaeogenetic study has revealed gene-flow from early modern humans into Neanderthal populations, and an 'African' haplotype 100 ka years in age implies inter-breeding at this time between the two populations (Kuhlwilm et al., 2016), lending further support to the late exit model.

The past decade or so has been an exciting period in the study of the early evolution of our species, as a number of previously unknown hominin populations have been recognised, either through the discovery of new fossils (e.g. H. floresiensis; Morwood, 2004, 2005) or inferred from the analysis of ancient DNA (aDNA) (e.g. the Denisovans and at least one other unnamed population; see Pääbo, 2014, 2015 for reviews). Furthermore, Late Pleistocene hominins with primitive morphologies from Southern China (e.g. Curnoe et al., 2010, 2015), and the metatarsal from Callao Cave dated to 67 ka (Mijares et al., 2010), that bears affinities with both modern humans and $H$. floresiensis, underscores the region as a melting pot of immigration and sporadic interbreeding (Pääbo, 2015). This implies that however bushy the Upper Pleistocene human family tree becomes, what is certain is that the reality of our evolution was most likely astonishingly complex.

The challenge facing scientists piecing together this story is that fossil find-spots are extremely scarce and widely distributed across a distance in excess of 10,000 $\mathrm{km}$ (Dennell, 2014). In fact, between the site of Tam Pa Ling (Laos) in the east (Demeter et al., 2012, 2015) and Skhul and Qafzeh (Levant) in the west (Grun and Stringer, 1991), the only securely dated and taxonomically-specific modern human fossils come from Sri Lanka (Perera et al., 2011; Roberts et al., 2015). Factors that doubtless play a part in this impoverished fossil record relate to the history of archaeological research in the region, the submergence of large landsurfaces, usually exposed during periods of lower sea level, and, most pertinently here, taphonomic issues associated with the hot and humid environments of the region.

\section{Evaluating the current state of play: Upper Pleistocene cave and rockshelter geoarchaeological research in Southeast Asia}

Southeast Asia has a long and rich history of prehistoric archaeological research. Recent fossil finds from the region have been fundamental in the development of early modern human colonisation models, and future finds are likely to be 
equally critical to our understanding of these dispersals. Game-changing fossils that hold the potential to re-write (and re-route) the history of our species must be excavated, recorded, and published with the detailed stratigraphic data. This is especially important because almost everything we know about human presence in the region has been recovered from caves and rockshelters that contain complex stratigraphic sequences. What is most likely to introduce uncertainty into the interpretation of the archaeological record is a lack of meticulous stratigraphic control during the excavation process of these sequences, and a poor understanding of the taphonomic and diagenetic processes that may have modified them. An integrated program of systematic geoarchaeological research can provide the level of assurance required, and already there is a discernable shift towards the publication of detailed stratigraphic information accompanying published hominin fossils (e.g. Demeter et al., 2015; Liu et al., 2010, 2015). Nonetheless, fully-integrated geoarchaeological research is still not widely undertaken, although notable exceptions do exist that I will examine below.

\subsection{The geoarchaeology of Upper Pleistocene hominin cave and rockshelter sites in Southeast Asia and Southern China}

The assessment of hominin fossil sites in Southeast Asia that follows includes sites from Southern China because its archaeological and landscape setting essentially forms a conterminous northward and eastward extension of Mainland Southeast Asia (MSEA). The number of fossil hominin sites in these regions is surprisingly small, but growing rapidly (Table 1; Figure 1), and here I will examine a representative sample, region by region, to explore how important fossil sites are published within a stratigraphic (geoarchaeological) framework.

\subsubsection{Southern China}

Southern China is proving to be a rich source of Upper Pleistocene hominin fossils (Bae et al., 2014; Curnoe et al., 2012, 2015; Liu et al., 2010, 2015). Nonetheless, archaeological research in this region has historically suffered from inadequate chrono-stratigraphic control. This can be linked to a combination of factors, including the longevity of archaeological investigation at a site, often with the initial discovery made by non-archaeologists (Bar-Yosef \& Wang, 2012), an over-reliance on coarse-resolution geological stratigraphy (Gao \& Norton, 2002), and the lack of an adequate dating program. The sites of Liujiang (Shen et al., 2002) and Zhirendong (Liu et al., 2010), for example, have allegedly produced very early modern human remains $(\sim 153-68 \mathrm{ka}$ and $\sim 113-100 \mathrm{ka}$, respectively), but either the stratigraphic information provided is equivocal, or the taxonomic status of the fossils is uncertain.

The situation is improving, however, demonstrated most recently by the discovery of the $\sim 80 \mathrm{ka} \mathrm{H}$. sapiens teeth from Fuyan Cave (Liu et al., 2015). These finds are particularly important as they support dispersal out of Africa earlier than some established models predicted (e.g. Stringer, 2000; Mellars, 2006; Mellars et al., 2013), and so precise stratigraphic context is absolutely vital. The authors go some way to achieve this by providing detailed supplemental stratigraphic information, although some caution is advised because it is unclear 
Table 1: Upper Pleistocene fossil hominin sites from Southeast Asia and Southern China

\begin{tabular}{|c|c|c|c|c|c|c|}
\hline Site & $\begin{array}{l}\text { Description of } \\
\text { material }\end{array}$ & $\begin{array}{l}\text { Age } \\
\text { (ka) }\end{array}$ & $\begin{array}{l}\text { Archaeology and } \\
\text { stratigraphic context }\end{array}$ & Existing or potential geoarchaeological work & $\begin{array}{l}\text { Archaeological } \\
\text { references }\end{array}$ & $\begin{array}{l}\text { Geoarch. } \\
\text { references }\end{array}$ \\
\hline \multicolumn{7}{|l|}{ MALAYSIA } \\
\hline $\begin{array}{l}\text { Niah Cave } \\
\text { (Borneo) }\end{array}$ & $\begin{array}{l}\text { H. sapiens } \\
\text { Partial } \\
\text { cranium }\end{array}$ & 46 & $\begin{array}{l}\text { The 'Deep Skull' } \\
\text { Secure context, although } \\
\text { associated with a guano } \\
\text { mudflow }\end{array}$ & $\begin{array}{l}\text { Geoarchaeological work at the site comprises a suite of } \\
\text { integrated micromorphological, geomorphological and } \\
\text { palaeoenvironmental analyses. }\end{array}$ & $\begin{array}{l}\text { Barker et al., 2007; } \\
\text { Barker, 2013, } 2016 \\
\text { in press }\end{array}$ & $\begin{array}{l}\text { Stephens et al., 2005, } \\
\text { 2016; Gilbertson et } \\
\text { al. 2005; Hunt and } \\
\text { Rushworth, 2004; } \\
\text { Hunt et al., 2007; } \\
\text { Dykes, 2007 }\end{array}$ \\
\hline \multicolumn{7}{|l|}{ PHILIPPINES } \\
\hline $\begin{array}{l}\text { Tabon Cave } \\
\text { (Palawan) }\end{array}$ & $\begin{array}{l}\text { H. sapiens } \\
\text { Mandible, skull } \\
\text { and long bone } \\
\text { fragments }\end{array}$ & $47-16$ & $\begin{array}{l}\text { Recent work at the site } \\
\text { recovered more faunal } \\
\text { material, but no } \\
\text { stratigraphic } \\
\text { information is provided }\end{array}$ & $\begin{array}{l}\text { Assessment-level micromorphological investigation of an } \\
\text { area of the sequence noted a suite of diagnostic features, } \\
\text { showing the presence of guano, phosphate and other } \\
\text { evidence for diagenesis; further work could have the } \\
\text { potential to reconstruct depositional environments }\end{array}$ & $\begin{array}{l}\text { Fox, 1970; Detroit et } \\
\text { al., 2004; }\end{array}$ & Lewis, 2007 \\
\hline $\begin{array}{l}\text { Callao Cave } \\
\text { (Luzon) }\end{array}$ & $\begin{array}{l}\text { H. sp. } \\
\text { Metatarsal }\end{array}$ & 66.7 & $\begin{array}{l}\text { Recovered from a secure } \\
\text { context, but with basic } \\
\text { stratigraphic } \\
\text { descriptions }\end{array}$ & $\begin{array}{l}\text { High potential for geoarchaeological work, but } \\
\text { stratigraphic profile and trench description indicates that } \\
\text { accessibility to sample at the base of the trench may be } \\
\text { difficult without further excavation }\end{array}$ & Mijares et al., 2010 & - \\
\hline \multicolumn{7}{|l|}{ INDONESIA } \\
\hline $\begin{array}{l}\text { Punung } \\
\text { (Java) }\end{array}$ & $\begin{array}{l}\text { H. sapiens } \\
\text { Tooth }\end{array}$ & $\begin{array}{l}126- \\
81\end{array}$ & $\begin{array}{l}\text { Allegedly forms part of } \\
\text { the Punung Fauna } \\
\text { (Storm et al., 2005), but } \\
\text { provenance uncertain } \\
\text { (Westaway et al., 2007) }\end{array}$ & $\begin{array}{l}\text { Extensive faunal assemblage recovered from several } \\
\text { remnant cave formations, including a single tooth. The } \\
\text { precise find-spot of the tooth is unknown; } \\
\text { Several localities exist, some of which may be amenable to } \\
\text { geoarchaeological research to establish precise } \\
\text { depositional history }\end{array}$ & $\begin{array}{l}\text { Storm et al., 2005; } \\
\text { Westaway et al., } 2007\end{array}$ & - \\
\hline $\begin{array}{l}\text { Wajak } \\
\text { (Java) }\end{array}$ & $\begin{array}{l}\text { H. sapiens } \\
\text { Crania and } \\
\text { assorted post- } \\
\text { axial elements }\end{array}$ & $\begin{array}{l}37- \\
29\end{array}$ & $\begin{array}{l}\text { Originally found in the } \\
\text { late } 1800 \text { 's. Original } \\
\text { location of finds } \\
\text { uncertain }\end{array}$ & $\begin{array}{l}\text { Very little chance to undertake geoarchaeological at the } \\
\text { exact find-spot, given the uncertainty surrounding this. } \\
\text { But now that the site has been rediscovered (Aziz and } \\
\text { Vos, 1989) }\end{array}$ & $\begin{array}{l}\text { Dubois, 1922; Storm et } \\
\text { al., } 2013\end{array}$ & - \\
\hline $\begin{array}{l}\text { Liang Bua } \\
\text { (Flores) }\end{array}$ & $\begin{array}{l}\text { H. floresiensis } \\
\text { Multiple } \\
\text { skeletal } \\
\text { elements }\end{array}$ & $\begin{array}{l}190- \\
50\end{array}$ & $\begin{array}{l}\text { Secure archaeological } \\
\text { context, little lithological } \\
\text { data }\end{array}$ & $\begin{array}{l}\text { Geomorphological reconstruction of site formation and } \\
\text { catchment evolution; } \\
\text { Detailed reconstruction of depositional environments } \\
\text { from area at rear of site using micromorphology and FTIR } \\
\text { geochemistry }\end{array}$ & $\begin{array}{l}\text { Morwood et al., } 2004 \text {, } \\
\text { 2005; } \\
\text { Sutikna et al., } 2016\end{array}$ & $\begin{array}{l}\text { Westaway 2009, a, b; } \\
\text { Roberts et al., 2009; } \\
\text { Morley et al., 2016; }\end{array}$ \\
\hline
\end{tabular}




\begin{tabular}{|c|c|c|c|c|c|c|}
\hline Tam Pa Ling & H. sapiens & $63-46$ & $\begin{array}{l}\text { Secure archaeological } \\
\text { context with detailed } \\
\text { stratigraphic } \\
\text { information }\end{array}$ & $\begin{array}{l}\text { Stratigraphic information is detailed, and basic } \\
\text { reconstruction of depositional environments represented } \\
\text { by the sediment sequence }\end{array}$ & $\begin{array}{l}\text { Demeter et al., 2012, } \\
2015\end{array}$ & - \\
\hline \multicolumn{7}{|l|}{ VIETNAM } \\
\hline Ma U'Oi & $\begin{array}{l}\text { H. sp. } \\
\text { Teeth }\end{array}$ & $63-46$ & $\begin{array}{l}\text { Palaeontological } \\
\text { assemblage }\end{array}$ & $\begin{array}{l}\text { Excellent appreciation of taphonomy and site formation } \\
\text { processes. Detailed description of sediments and } \\
\text { depositional environments, but without quantitative data }\end{array}$ & $\begin{array}{l}\text { Demeter et al., 2004, } \\
\text { 2005; Bacon et al., } \\
\text { 2006; }\end{array}$ & - \\
\hline $\begin{array}{l}\text { Duoi U'Oi } \\
\text { (Man Duc) }\end{array}$ & $\begin{array}{l}\text { H. sp. } \\
\text { Teeth }\end{array}$ & 66 & $\begin{array}{l}\text { Palaeontological } \\
\text { assemblage }\end{array}$ & $\begin{array}{l}\text { Excellent appreciation of taphonomy and site formation } \\
\text { processes. Detailed description of sediments and } \\
\text { depositional environments, but without quantitative data } \\
\text { (e.g. geochemistry) }\end{array}$ & $\begin{array}{l}\text { Bacon et al., 2006, } \\
\text { 2008; }\end{array}$ & - \\
\hline Lang Trang & $\begin{array}{l}\text { H. sp. } \\
\text { Teeth }\end{array}$ & $80-60$ & Cave site & Mammal assemblage & $\begin{array}{l}\text { Long et al., } 1996 \\
\text { Bacon et al., } 2008\end{array}$ & - \\
\hline Hang Hum & $\begin{array}{l}\text { H. sp. } \\
\text { Teeth }\end{array}$ & $\begin{array}{l}140- \\
80\end{array}$ & Cave site & $\begin{array}{l}\text { No information (cited in Bacon et al., 2008; Dennell, } \\
\text { 2014) }\end{array}$ & Bacon et al., 2008 & - \\
\hline \multicolumn{7}{|l|}{ THAILAND } \\
\hline Mohh Kiew & $\begin{array}{l}\text { H. sapiens } \\
\text { Partial } \\
\text { skeleton }\end{array}$ & 26 & Cave site & No information & Pookajorn, 1996 & - \\
\hline \multicolumn{7}{|c|}{ SOUTHERN CHINA } \\
\hline $\begin{array}{l}\text { Maludong \& } \\
\text { (Longlin) }\end{array}$ & $\begin{array}{l}\text { H. sp. } \\
\text { Various } \\
\text { skeletal } \\
\text { elements }\end{array}$ & $\begin{array}{l}18-13 \\
(11)\end{array}$ & $\begin{array}{l}\text { No stratigraphic } \\
\text { information for Longlin } \\
\text { specimen; } \\
\text { Some limited } \\
\text { stratigraphic data for } \\
\text { Maludong }\end{array}$ & $\begin{array}{l}\text { Magnetic susceptibility measurements as coarse } \\
\text { palaeoclimate proxy; } \\
\text { Bones collected in the } 1970 \text { 's and 1980's from a site that } \\
\text { is now inaccessible (Longlin), and one that has limited } \\
\text { new excavation (Maludong). Potential for further } \\
\text { stratigraphic work at Maludong }\end{array}$ & $\begin{array}{l}\text { Curnoe et al., 2012, } \\
2015\end{array}$ & - \\
\hline Liujiang & H. sapiens & $\begin{array}{l}\sim 68 \\
\sim 139 \\
-111\end{array}$ & $\begin{array}{l}\text { Uncertain provenance of } \\
\text { fossil material }\end{array}$ & $\begin{array}{l}\text { Very basic stratigraphic information. Originally } \\
\text { discovered by miners in } 1958 \text { and exact provenance } \\
\text { remains unclear }\end{array}$ & Shen et al., 2002 & - \\
\hline Zhirendong & $\begin{array}{l}\text { H. sapiens } \\
\text { Two molars \& } \\
\text { partial } \\
\text { mandible }\end{array}$ & 100 & $\begin{array}{l}\text { Secure context, but } \\
\text { dated flowstone far from } \\
\text { human remains }\end{array}$ & $\begin{array}{l}\text { Context appears to be secure but the flowstones, where } \\
\text { dated, are very close together (Figure S6, Liu et al., 2010) } \\
\text { and it is difficult to assess the amount of recrystallisation } \\
\text { of calcium carbonate, if any }\end{array}$ & Liu et al., 2010 & - \\
\hline Fuyan Cave & $\begin{array}{l}\text { H. sapiens } \\
\text { Teeth }\end{array}$ & $\begin{array}{l}120- \\
80\end{array}$ & $\begin{array}{l}\text { Secure context, but } \\
\text { depositional } \\
\text { environment of the } \\
\text { sediments unknown. }\end{array}$ & $\begin{array}{l}\text { Assessment of the linear integrity of the flowstone would } \\
\text { allay any doubts as to the contiguousness of this layer } \\
\text { over a large distance in the cave }\end{array}$ & Liu et al., 2015 & - \\
\hline
\end{tabular}


whether the flowstone on which the dated stalactite formed is contiguous with the flowstone overlying the teeth, given the $\sim 10-20 \mathrm{~m}$ that separate them (Liu et al., 2015). Further macro- and micro-stratigraphic descriptions of the flowstone and its lateral variability, if any, would have bolstered their interpretation.

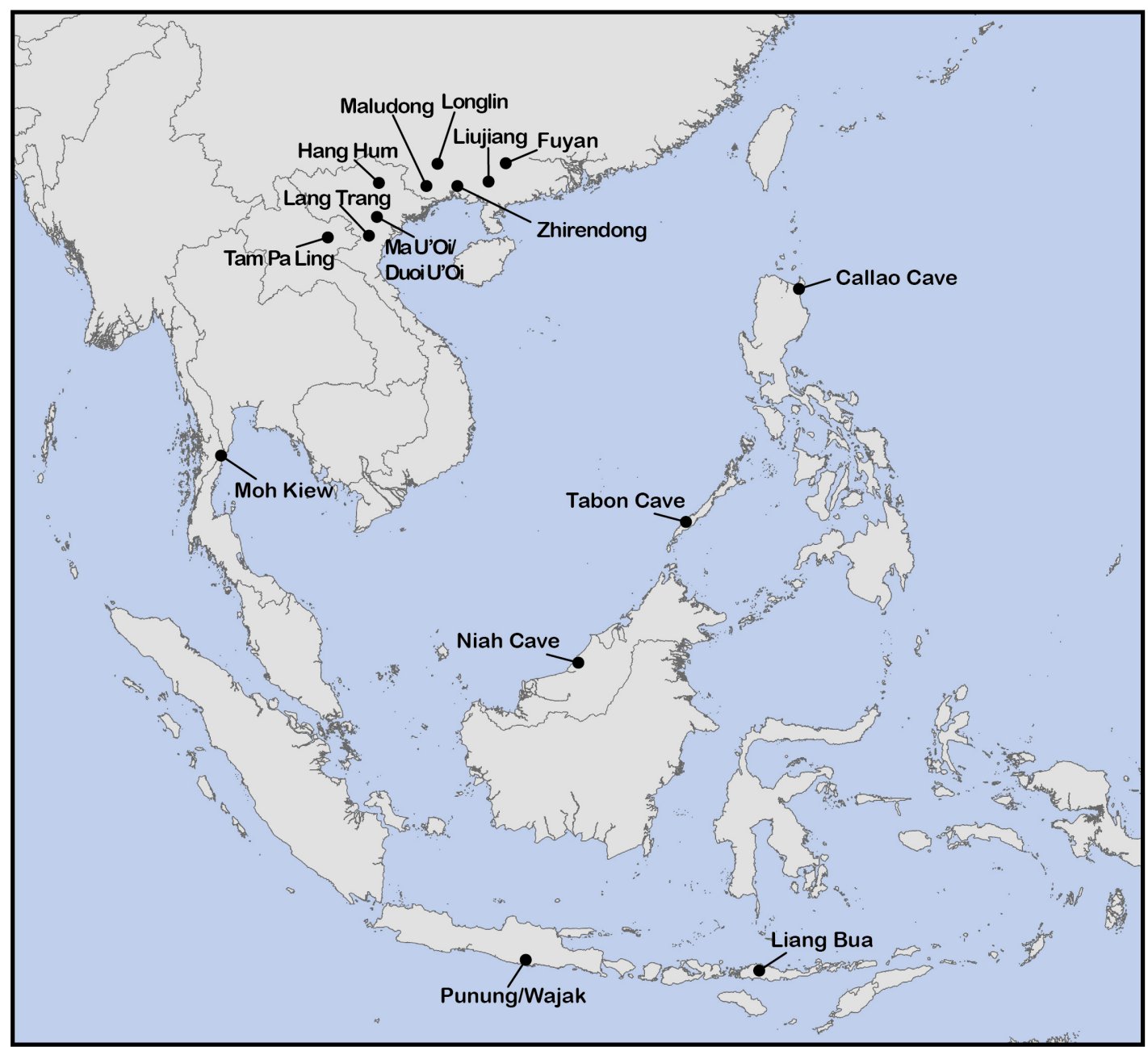

Figure 1: map of Southeast Asia with key sites mentioned in text and Table 1 marked.

\subsubsection{Mainland Southeast Asia (MSEA)}

11 Mainland Southeast Asia (MSEA; here defined as Myanmar, Thailand, Laos, Cambodia, Vietnam and Peninsula Malaysia has produced some high quality Palaeolithic archaeology (e.g. Pookajorn, 1996; Schepartz et al., 2000; Mudar and Anderson, 2007; Bellwood, 2014; Higham, 2014; Demeter et al., 2015), but has yielded disappointingly low numbers of hominin fossils (Marwick, 2009). Where material has been recovered, this has generally been limited to isolated teeth that lack precise stratigraphic information or uncertain taxonomic status (e.g. Storm et al., 2005, 2013; Bacon et al., 2008, 2015). Recent work at Tam Pa Ling, Laos, is beginning to alter this picture, having produced some of the earliest modern human fossils in the entire SEA region, dated to a minimum age of $\sim 63-$ 46 ka (Demeter et al., 2012a; 2015). The work at Tam Pa Ling also sets somewhat of a precedent in the region, with the provision of some very robust stratigraphic data and a basic depositional environment reconstruction 
(Demeter et al., 2015). To highlight the level of scrutiny important fossil finds are likely to attract, initially there were some claims of stratigraphic and dating inconsistencies (Demeter et al., 2012b; Pierret et al., 2012). A subsequent publication has clarified these issues (Demeter et al., 2015), and is a very good example of key fossil finds accompanied by robust stratigraphic data that support their interpretation. It is worth noting here that fossils consistently published with scientifically-robust stratigraphic data are palaeontological studies, including a raft of research from Northern Vietnam (e.g. Bacon et al., $2006,2008,2015)$, where reconstructing the taphonomic history of a faunal assemblage necessitates rigorous attention to stratigraphic and sedimentological detail.

\subsubsection{Island Southeast Asia (ISEA)}

The timing, route and environmental context of modern human dispersals across Island Southeast Asia (ISEA) have recently garnered considerable scrutiny (Birdsell, 1977; Morwood et al., 2004, 2005; O'Connor, 2007, 2015; O'Connell et al., 2010; Dennell and Petraglia, 2012; O'Connor et al., 2012; Dennell et al., 2014; O'Connell and Allen, 2015). This is in part due to dispersal models having to factor both the changing palaeogeography of the Sunda Shelf, associated with Quaternary sea level change (Voris, 2000; Lambeck and Chappell, 2001; Bird et al., 2005), and the permanent sea crossings necessitated by west-to-east traverses of Sunda and Wallacea before arrival in Sahul (Roberts et al., 1990, 1994; Bowler et al., 2003; Allen and O'Connell, 2008; O'Connell et al., 2010; Bellwood, 2014; O'Connell and Allen, 2015; Clarkson et al., 2015; O'Connor, 2015).

Niah Cave, Malaysian Borneo, has provided one of the earliest ( 45-39 ka) unequivocal human fossils from ISEA (Barker et al., 2007; Barker, 2013, 2016). A major multi-disciplinary re-analysis of the site has generated a significant quantity of archaeological and palaeoenvironmental data, significantly advancing our knowledge of early modern human adaptations to rainforest environments (Barker, 2013, 2016). This includes several detailed geoarchaeological and palaeoenvironmental studies focussing on the microstratigraphy and geomorphology of the archaeological sequence (Gilbertson et al., 2005; Hunt and Rushworth, 2005; Stephens et al., 2005, 2016, this volume; Dykes, 2007; Hunt et al., 2012). The initial micromorphological study by Stephens et al. (2005) was somewhat limited in scope, focussing as it did on sediments primarily associated with the 'Deep Skull'. New research affords far greater coverage of the stratigraphic profile enabling reconstruction of post-depositional environments (Stephens et al. 2016, this volume). The work at Niah has been instrumental in underscoring the utility of a wide-ranging, multi-disciplinary project in integrating archaeological, geoarchaeological and palaeoenvironmental datasets.

Moving north from Borneo, Tabon Cave, Palawan, Philippines, has provided some of the most important modern human fossils from ISEA (Fox, 1970; Macintosh et al. 1978; Dizon et al., 2002; Pawlik et al., 2014). A further phase of work at the site contributed a new assemblage of modern human fossils (Detroit et al., 2004), albeit with an absence of stratigraphic information. Given the wide scatter of direct-dated U-series ages obtained from the bones ( $\sim 58-24 \mathrm{ka})$, and the admission that "human fossils of various ages [are] compatible with...a 
disturbed stratigraphic context" (Detroit 2004: 710), it is highly likely that only with renewed analyses of the stratigraphy will the provenance and age of these important fossils be fully realised. A micromorphological assessment by Lewis (2007) ultimately proved too narrow in scope to clarify these stratigraphic ambiguities, although useful data was generated regarding the landscape setting of the site and potential diagenetic alteration of elements of the sedimentary sequence. Also in the Philippines, Callao Cave, Luzon, has yielded a metatarsal of genus Homo dating to $\sim 67 \mathrm{ka}$ (Mijares et al., 2010), which if belonging to $H$. sapiens would represent the oldest modern human fossil from SEA. The bone was recorded from a very restricted area at the base of the sequence, unfortunately providing scant information regarding the broader stratigraphic context of this important find. Further geoarchaeological work might provide this much-needed contextual information.

The recent re-dating of the $H$. floresiensis fossils and revision of the stratigraphy at the type-site, Liang Bua, Flores, Indonesia (Sutikna et al, 2016), has highlighted how initial interpretations of a stratigraphic sequence (Morwood et al., 2004, 2005) can differ markedly from those made during subsequent excavations when lateral coverage is extended. An unconformity present in the area in which the bones were originally recovered-most likely caused by water erosion-was not initially apparent due to limited spatial observation of the stratigraphy, resulting in errors being introduced into the interpretation and dating of the stratigraphy as then exposed. A program of geoarchaeological research has recently been initiated at the site, and initial micromorphological work is proving promising (Morley et al., 2016, this volume).

\subsection{Geoarchaeology is not optional!}

As the data above has shown, fossil finds are rarely published with detailed geoarchaeological consideration of the site stratigraphy. It should be emphasised here-though not impartially some may feel-that geoarchaeological research should not be considered an optional component of archaeological investigation, although this is not a regional-specific problem of course (see Goldberg and Macphail, 2008). Future Upper Pleistocene fossils from the region should be considered rare and non-renewable resources, too precious for the introduction of stratigraphic ambiguities. The picture that is emerging from the region is that there is a growing awareness of the utility of geoarchaeological science, but this is still rarely undertaken to reconstruct the formation of the archaeological site and fully contextualise archaeological material.

\section{It's a Jungle Out There: The Pitfalls and Problems of Undertaking Geoarchaeological Research in the Humid Tropics}

"The caves and rockshelters of Southeast Asia present formidable challenges in terms of the geomorphological and taphonomic processes that have formed and transformed their sediments, processes that in many respects are far less understood than for caves in other environments" (Barker et al. 2005) 
The principal challenge for archaeologists and geoarchaeologists working in Southeast Asia lies in that much of the region falls within Köppen's humid tropical climate classification (Köppen, 1923). As such, it is often wet, hot and densely vegetated, making prospection, survey and excavation an arduous and challenging endeavour (Figure 2a,b). These problems are exacerbated because archaeological sites can be interred beneath thick tropical soils and humus (Hunt et al., 2012), that may accommodate extensive root systems, tens of metres in depth (e.g. Maeght et al., 2013). Extensive karst landscapes in the region (Figure 2c) are highly susceptible to speleogenesis (Bacon et al., 2006; Duringer et al., 2012), and the sediments that fill these caves and rockshelters-and the fossils contained within them-can deteriorate significantly through aggressive heat and humidity-driven chemical diagenesis, severe bioturbation, and physical erosion (Gillieson, 1986; Anderson, 1997; Stephens et al., 2005; Dykes, 2007). It is because tropical geomorphological processes are so poorly constrained (Gupta, 1993, 2011), no less in the cave systems of the region (Gillieson, 1986), that archaeological scientists should pay special attention to the regional-specific processes that form, degrade and preserve an archaeological site (Table 2).

Notwithstanding our slender understanding of tropical geomorphological systems, recent research is beginning to recognise tropical site formation processes, with studies from South America (Araujo et al., 2008), Africa (e.g. Mercader, 2002; Mercader et al., 2003; Kourampas et al., 2015; Wright et al., 2016, this volume), South Asia (Kourampas et al., 2009) and Southeast Asia (Glover, 1979; Gilbertson et al., 2005; Lewis, 2007; Mijares and Lewis, 2009; Rabett et al., 2011; Morley et al., 2016, this volume;). This is timely as growing evidence shows that tropical rainforests, far from being unfavourable for human exploitation as was traditionally thought (see e.g. Bailey et al., 1989), have been successfully exploited for the past 50,000 years or so (Anderson, 1997; Mercader, 2002; Storm et al., 2005; Perera et al., 2011; Roberts et al., 2015; Roberts and Petraglia, 2015; Barker et al., 2007; Hunt et al., 2012; Rabett, 2012; Jones et al., 2015; Summerhayes et al., 2010, 2016; Rabett et al., 2016, in press). Eastward colonisation of Southeast Asia need not have required adaptation to rainforest environments, however, as an open savannah corridor may have bisected the Sunda Shelf during the Last Glacial Period, MIS4-2 (Bird et al., 2005, 2007; Wurster et al., 2010). Anderson (1997) claims that even dense rainforests were not ecologically homogeneous, and past human populations would have exploited specific areas for particular resources.

\subsection{Reconstructing the life and death of an archaeological site: site formation processes, geoarchaeology and its application in humid tropical environments}

Reconstructing the life history of an archaeological site is vital, not only to identify the taphonomic pathways along which archaeological material travelled to a site, but also to evaluate the depositional and post-depositional history of the stratigraphic sequence. Without this understanding of archaeological site formation processes it is very difficult-perhaps impossible- to infer human behaviour from archaeological patterns (Schiffer, 1972, 1987). Geoarchaeology is the discipline that is most suited to elucidate these processes in humid tropical environments. Here I will briefly review the site formation processes most commonly encountered in the humid tropics (Table 2). 

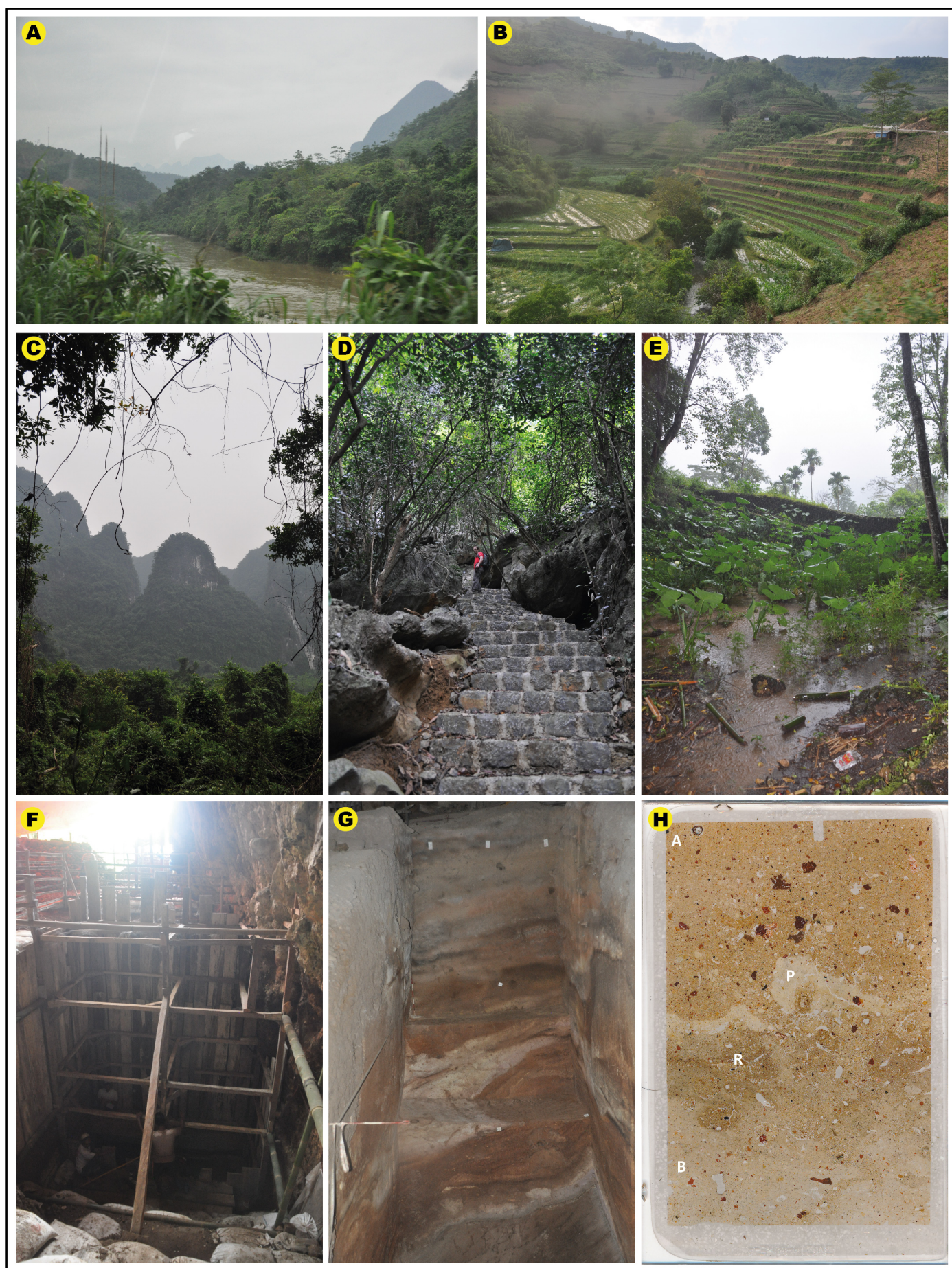

Figure 2: a) densely vegetated river valley in Northern Vietnam. Geomorphological survey is very difficult in this tropical landscape; b) extensive terraced paddy fields completely obscure fluvial geomorphological landforms in this river valley in northern Vietnam; c) classic tower karst terrain that covers large swathes of MSEA and Southern China; d) over 1000 steep steps to Hang Trong Cave, situated high in the tower karst of northern Vietnam; e) seasonal rains flood the entrance to Liang Bua on a daily basis during the wet season; f) deep excavations can mean working in hot, humid and cramped conditions (Liang Bua); g) extreme chemical diagenesis of sediments at Con Moong Cave, Northern Vietnam. This convoluted stratigraphy probably represents load structures related to mass movements of guano, as recorded at Niah Cave; $h$ ) thin section from Con Moong Cave showing pinkish layer (A), originally rich in guano, and underlying greyish layer (B), originally rich in carbonates. The acidic, phosphate rich, decomposing guano has decalcified the upper part of the underlying layer, resulting in the formation of an unidentified phosphate mineral (P) and the precipitation of an unidentified compound below (R) (Mcadams, unpublished data) 
2 Diagenesis includes all of the processes that can modify the archaeological 3 record, whether by physical, biological or chemical agency (Karkanas et al., 4 2000). These processes hold the potential to cause major losses of archaeological 5 and palaeoenvironmental information (e.g. Stiner et al., 2001; Hunt and 6 Rushworth, 2003; Lewis, 2007; Bacon et al., 2008; Piper and Rabett, 2009; van 7 den Bergh et al., 2009; Mijares et al., 2010; Faylona et al., 2011; Szabo and 8 Amesbury, 2011; Canti and Huisman, 2015; Morley et al., 2016, this volume; 9 Stephens et al., 2016, this volume; Wright et al., 2016, this volume). Chemical 10 diagenesis is accelerated in tropical environments because of the presence of 11 percolating water (Gupta, 1993; Goldberg and Macphail, 2006; Weiner, 2010) (Figure 2g,h). Identifying where this has occurred in a stratigraphic sequence can greatly assist in evaluating the completeness of the archaeological record (Goldberg and Sherwood, 2006; Weiner, 2010).

Table 2: Tropical geomorphological, meteorological and biological parameters that may affect archaeological sediments and drive site formation processes in humid tropical environments

\begin{tabular}{|c|c|}
\hline Parameter & Effect \\
\hline \multicolumn{2}{|c|}{ Heat and humidity } \\
\hline & $\begin{array}{l}\text { - Increased diagenesis causing chemical modification of sediments } \\
\text { and components } \\
\text { - } \quad \text { Leaching, mottling and blurring of sediment interfaces } \\
\text { - } \quad \text { Hinders the ability to work comfortably } \\
\text { - Increased microbial action } \\
\text { - } \quad \text { Enhanced leaching of mobile minerals, such as calcareous } \\
\text { anthropogenic ash } \\
\text { - Poor preservation of biomarkers such as DNA }\end{array}$ \\
\hline \multicolumn{2}{|c|}{ Well-developed tropical soils } \\
\hline & $\begin{array}{l}\text { - } \quad \text { Archaeological visibility reduced (burial) } \\
\text { - } \quad \text { Deeper excavations required to reach lower levels }\end{array}$ \\
\hline \multicolumn{2}{|c|}{ Seasonal rainfall (monsoons) } \\
\hline & $\begin{array}{ll}\text { - } & \text { Flooding of archaeological sites (past and present) } \\
\text { - } & \text { Erosion and truncation of archaeological deposits } \\
\text { - } & \text { Fieldwork restricted to particular time of year } \\
\text { - } & \text { Accessibility of archaeological sites (river levels) }\end{array}$ \\
\hline \multicolumn{2}{|c|}{ Dense vegetation cover } \\
\hline & $\begin{array}{l}\text { - Archaeological visibility reduced (concealed at ground level and } \\
\text { from aerial mapping \& imaging): use of LiDAR and Radar active } \\
\text { remote sensing technology required } \\
\text { - } \quad \text { Survey hampered, no clear line of sight, view-shed restricted } \\
\text { - } \quad \text { Intense bioturbation of sub-surface sediments (root action) }\end{array}$ \\
\hline \multicolumn{2}{|c|}{ Increased biological activity } \\
\hline & $\begin{array}{l}\text { - } \quad \text { Bioturbation (termite, wasp burrowing) } \\
\text { Deposition of guano, increased acidity, dissolution of mobile } \\
\text { elements of archaeological stratigraphy }\end{array}$ \\
\hline \multicolumn{2}{|c|}{ Enhanced rock weathering } \\
\hline & $\begin{array}{l}\text { - Higher sedimentation rates creating very thick sedimentary } \\
\text { sequences } \\
\text { - High clay content causing cracking of sediment blocks and imperfect } \\
\text { penetration of resin during impregnation }\end{array}$ \\
\hline \multicolumn{2}{|c|}{ Mass movements } \\
\hline & $\begin{array}{l}\text { - Slumping of super-saturated sediment mixing archaeological } \\
\text { sediments } \\
\text { - } \quad \text { Archaeological visibility (site burial) }\end{array}$ \\
\hline
\end{tabular}


An important method for the reconstruction of the 'chemical history' of an archaeological sequence is through the analysis of specific minerals (authigenic minerals) that form under particular chemical conditions (Karkanas et al., 2000; Weiner et al., 2002). The spatial mapping of authigenic minerals across a stratigraphic profile or micromorphological thin section can greatly assist in understanding the degree to which chemical diagenesis has modified a sedimentary sequence (Goldberg and Sherwood, 2006), and has been successfully employed at a number of sites in Southwest Asia and South Africa (e.g. Karkanas et al., 2000; Weiner et al., 2002; Karkanas and Goldberg, 2010; Weiner, 2010; Miller et al., 2013). Shahack-Gross et al. (2004) have estimated that authigenic minerals form in relatively short periods of time (in the order of decades) and so the utility of analysing these assemblages to derive information about penecontemporaneous environments of deposition are manifest. In SEA there have been a number of micromorphological and geochemical characterisations of authigenic mineral production and the environments in which these have formed (e.g. Lewis, 2008; Stephens et al., 2016, this volume), but it is still far from clear how tropical baseline conditions affect their formation.

Scientifically-robust assessments of the degree of diagenesis archaeological materials have been subjected to need to be more routinely employed in future work in the region, especially so if their suitability for palaeoenvironmental analysis depend on their diagenetic history. An insightful study by Faylona et al. (2011) evaluated the diagenetic modification of shells (giant clams) from a rockshelter in the Philippines using scanning electron microscopy and microFTIR to look for evidence of dissolution and recrystallization. They conclude that diagenetic degradation of shells can alter their isotopic composition, thus precluding their use as a palaeoenvironmental indicator.

Tropical environments are unfavourable for the preservation of organic molecules and biomarkers (e.g. Gibbons, 2015), including aDNA, the study of which is an important tool for reconstructing Upper Pleistocene modern human demographics. Recent research in equatorial Africa has had some success extracting genetic material (Llorente 2015), and work in Southeast Asia is ongoing, including a study currently in progress at Liang Bua. At present we know surprisingly little about DNA preservation in the humid tropics. It will be extremely profitable to reconstruct the depositional and post-depositional environments from which samples for biomarkers and organic molecules are taken, so that we can begin to compile sufficient data to target future sampling programs.

\subsubsection{Bat and bird guano as a diagenetic accelerant}

Bat and bird guano is common in caves (and less so in rockshelters that are generally more shallow) across the globe (Schiegel et al., 1996; Karkanas et al., 2002; Weiner et al., 2002; Shahack-Gross et al., 2004), but in tropical regions extensive bat populations can produce very thick $(>9 \mathrm{~m}$ recorded at Niah Cave, Gilbertson et al., 2005) deposits of the material that breakdown producing phosphates (e.g. Anderson, 1997; Hunt and Rushworth, 2004; Gilbertson et al., 2005; Bird et al., 2007; Lewis, 2007; Stephens et al., 2016, this volume). The pH of percolating water can be lowered due to the presence of these phosphates, 
thus enhancing the dissolution of mobile minerals and organic materials that interact with this water, so identifying guano in stratigraphic or microstratigraphic contexts is a key goal for future geoarchaeological research in the region. Contrary to its role as a limiting factor in interpreting the archaeological record, guano is proving to be a useful repository of palaeoenvironmental data using stable-isotope analysis to derive high-resolution records of climate-driven vegetation change (Bird et al., 2007; Wurster et al., 2013, 2015; Choa et al., 2016).

At Tabon Cave, Philippines, Lewis (2007) reports highly phosphatised and degraded bones, most likely the result of guano recorded in thin section throughout much of the studied sequence, and at Niah Cave, Stephens and colleagues (2016, this volume) record phosphate 'lumps' in this section, which they also associate with guano diagenesis. At Liang Bua, direct evidence for guano is not recorded, but the complete phosphatisation of a thick (50 mm) flowstone, identified optically and through FTIR analysis, strongly suggest the past presence of guano at the site (since stripped from the flowstone surface) despite a lack of evidence in the macro- or micro-stratigraphy (Morley et al., 2016, this volume). It should be added that phosphates in cave sediments can also derive from the in-situ dissolution of bone (Goldberg and Nathan, 1975; Karkanas et al. 2002; Weiner et al. 2002), but in the latter case this is unlikely given the stratigraphic associations. Because authigenic phosphates are formed under specific environmental (chemical) conditions, their presence in the sedimentological record can reveal information about the syn- and postdepositional chemical environments prevailing at the site.

\section{Although it is assumed that the heat and humidity of the humid} tropics accelerates diagenesis and the degradation of archaeological cave sediments, there has to date been limited work undertaken to test this hypothesis (Kourampas, 2009). Wurster et al. (2015) recorded characteristic suites of minerals within cave guano from SEA that broadly mirrored those recorded in sediments from non-tropical zones. The preservation of soluble minerals such as gypsum may suggest their use as palaeoenvironmental indicators (C. Mcadams, pers. comm.). Future research on the effect of guano on tropical archaeological sediments should map the spatial geochemistry of sediments observed in micromorphological thin sections (e.g. by using FTIR) to preserve the associations between the guano and the other components of the stratigraphy (Mcadams, 2016). Three-dimensional mapping of mineral distributions, as undertaken by Weiner et al. (2002) at Hayonim Cave, Israel, will serve as useful baseline data that can ultimately be compared to future work in the humid tropics.

\subsubsection{Speleothem and breccia formation in tropical caves} The sedimentary fills of caves and rockshelters located in the humid tropics differ in some fundamental ways to their counterparts in temperate and semiarid climates (pers. obs.). Coarse gravel layers that are so common in Western Europe, for example, are rarely encountered in the tropics (but see Araujo et al., 2008), presumably due to generally warmer annual temperatures and a concomitant lack of cryoclastic activity. Cave breccias (cemented, angular gravels) are commonly found in the caves or Southeast Asia, and often contain 
archaeological and palaeoenvironmental material (Bacon et al., 2008; O'Connor et al., 2016, this volume). Defining the mode of formation of these sediment bodies is extremely important (O'Connor et al., 2016, this volume) as archaeological and palaeontological material recovered from them may have complex taphonomic histories, and the mode of their formation could serve as a useful palaeoclimatic proxy.

Speleothems are ubiquitous in humid tropical caves (Gillieson, 1986; Bacon et al., 2008; Lewis et al., 2008); Duringer et al., 2012; O'Connor et al., 2016, this volume), where they often form useful associations with archaeological material. Tabular flowstones are especially prevalent, formed by the flow of water across an inclined surface, potentially sealing ancient cave floor surfaces that are impermeable, thus inhibiting sub-surface flow (Morley et al., 2016, this volume). The presence of a flowstone can act as protection for archaeological material beneath, but at Liang Bua it has been mooted that the existence of a flowstone will concentrate over-ground flow of water to lower-lying areas, potentially increasing the erosive capability of the water-flow (pers. obs.). As we have seen above at Fuyan Cave, Southern China, flowstones capping archaeological material can be used as chronostratigraphic markers, but care is needed to ensure that the flowstone forms a continuous surface, and that diagenesis of the flowstone will not affect radiometric-dating techniques.

\subsubsection{Volcanism and tephra deposition}

It would be remiss to discuss the archaeology of Southeast Asia without mentioning the spectacularly violent tectonic forces that have shaped-and continue to shape - the region. Southeast Asia has more active volcanoes than any other region on Earth owing to its location in a subduction zone (the Banda Volcanic Arc) where the crust of the Indian Ocean is forced beneath the continental Asian plate (Corlett, 2014). Volcanic ash can form very useful associations with archaeological material, potentially providing a laterally extensive chronostratigraphic marker if it is recorded in primary position (e.g. Morley and Woodward, 2011). The Toba super-eruption of $\sim 74$ ka caused an ash fall-out that extended westwards over a great part of the Indian sub-continent, capping archaeological sites, the relative dating of which have provided valuable insights into the early human colonisation of Southern Asia (e.g. Petraglia et al., $2007,2011)$. On a site level, the presence of morphologically and geochemically distinct layers of ash can aid in the correlation of natural and anthropogenic features across spatially disparate excavation trenches (e.g. Sutikna et al., 2016).

In the humid tropics, what is not clear is how water percolating through layers of volcanic ash might lower $\mathrm{pH}$ and increase the likelihood of dissolution of underlying sediments. Research on tephras from historic eruptions has shown that only those rich in sulphur are likely to have high acid-loading (Self and Gertisser, 2015), so potentially this can be measured during the routine geochemical characterisation of tephras, usually undertaken to source the eruptive origin of the ash (e.g. Gatti et al., 2014). What is certain is that tephras are likely to be a common occurrence in sedimentary sequences infilling caves and rockshelters in Southeast Asia, so the possible effects of the ash chemistry (and possibly temperature) should be borne in mind in future research in the region. 


\subsubsection{Bioturbation}

2 Tropical caves and rockshelters are biologically-rich, making them attractive habitats for a wide range of animal and plant life. Direct physical evidence of bioturbation, in the form of gnawing marks on archaeologically-significant faunal material, is often encountered in tropical sites, caused by cave dwelling animals such as armadillos, porcupines and other rodents (Araujo and Marcelino, 2003; Araujo et al. 2008; Bacon et al. 2015). Porcupines are particularly relevant to Southeast Asian records as they can be responsible for intensive gnawing of faunal assemblages, especially the roots of teeth (Long et al., 1996; Bacon et al., 2015). This also means that affected faunal assemblages are likely to be taphonomically-biased due to post-depositional curation of bones by other animals (Brain, 1983). Disturbance of a stratigraphic sequence by invertebrates such as ants, termites, wasps and earthworms, is similarly common (e.g. Stephens et al., 2005). Termites are likely to have a significant effect on the effectiveness of OSL dating methods because of the sediment turnover during mound construction (Venn, 2016). At Con Moong Cave, Vietnam, large areas of the Pleistocene sequence are burrowed by small insects (Morley et al., in prep), possibly the robber wasps seen in Niah Cave today (Stephens et al., 2005). Bioturbation by penetrating roots can cause severe disturbance of buried stratigraphy, leading to the vertical mixing of archaeological materials in extreme cases (O'Connor et al., 2010) and issues with various dating techniques, but even minor disturbance should be recognisable in micromorphological thin section.

\subsubsection{Physical erosion of archaeological stratigraphy linked to monsoon intensity} Periods of intense and short-lived rainfall linked to monsoonal weather patterns (Figure 2e) can trigger a range of mass-movements in tropical regions (Gillieson, 1986; Gupta, 1993), and these can be prevalent in caves and rockshelters (Dyke, 2007; Hunt et al., 2015) as well as in the wider landscape. Sedimentary fills of caves that have connections to the karst hydrogeological system may experience phases of truncation and localised erosion caused by high-energy water ingress events, resulting in unconformities in the stratigraphic sequence at a site. As previously mentioned, recent work at Liang Bua, Flores, reported a major unconformity in the stratigraphic sequence that had major implications on the chronology of the fossil-bearing sediments preserved at the site (Sutikna et al. 2016).

The slumping and mass-movement of saturated sediments can possess sufficient erosive force to truncate cave sediments (Gillieson 1986), or at least partially rework their upper surfaces (Stephens et al. 2005, 2016, this volume). This process may deposit poorly-sorted diamicts which have distinctive micromorphological attributes of included mineral grains (Gillieson, 1986). A large $\left(\sim 600 \mathrm{~m}^{3}\right)$ mass movement of guano recorded at Niah Cave (Dykes, 2007), is of particular importance given the association with the 'Deep Skull'. Geotechnical measurements of guano samples showed that it was "highly susceptible to failure by hydrocollapse" (Dykes, 2007: 287), suggesting that the slumping at Niah was caused by periodic high-intensity water input to the site. At Con Moong Cave, Vietnam (Morley et al., in prep.), highly distinctive load structures observed in the Upper Pleistocene deposits (Figure 2g), similar to those recorded at Niah (Gilbertson et al., 2005), likely have the same origin, as 
super-saturated guano deposits slumped onto a deformable sediment substrate. Such major deformations of sedimentary sequences in caves in the region have the capacity to confuse the interpretation of included archaeological material.

\subsection{Logistical issues conducting fieldwork in the humid tropics}

Conducting fieldwork in the humid tropics can be challenging due to the elevated temperature and humidity levels, and the densely vegetated and often difficult terrain. Hot and humid environments are physically demanding on a general personal level, but also serve to hinder essential components of geoarchaeological research such as geomorphological survey, the recording of stratigraphic sequences, and sediment sampling. In the planning stage of an archaeological project, vegetation cover and forest canopy seriously impede the analysis of satellite images and aerial photographs. Recently, the use of LiDAR to map otherwise concealed landscapes and archaeological sites has been shown to circumvent these problems to some extent (e.g. Chase et al. 2011).

In terms of site prospection, archaeological site visibility can be significantly reduced (Figure $2 \mathrm{a}$ ), concealed either by vegetation or buried beneath thick tropical soils, making even the search for known sites to be a difficult process (Anderson, 1997). Of course, the help of local guides can greatly assist with these endeavours, and close collaboration with local people is always beneficial as well as enjoyable. Geomorphological survey can be hampered by the presence of paddy fields that represent major modifications of the natural geomorphology. For example, ancient river terraces may be completely obliterated by these earthworks (pers. obs.) (Figure 2b). We should also bear in mind modern anthropogenic disturbance of archaeological sites, in the guise of guano/soil collectors and amateur antiquities enthusiasts (Anderson, 1997).

Admittedly, caves and rockshelters do temper the extremes of tropical heat and humidity to some degree, but working on-site in excavation trenches can be particularly unforgiving depending on the geomorphological setting and aspect of the cave mouth. Discomfort levels can, however, be increased by an order of magnitude when excavation trenches are deep, potentially up to or even exceeding $10 \mathrm{~m}$ (Figure 2f). In these cases, still air coupled with very high humidity can render conditions impossible to work in effectively for extended time periods (pers. obs.). Given that generators are usually used to provide light at these depths, a useful and inexpensive addition to a site equipment list would be an electric fan to circulate the air, potentially providing some respite. The marked increase in humidity at depth can also have ramifications for recording and sampling. As an example, gypsum plaster-impregnated bandages, commonly used to facilitate the extraction of intact blocks of sediments from exposed profiles, have a much longer hardening time in very hot and humid conditions. Problems can make their way back to the laboratory, as partially saturated sediment blocks require very careful processing (specifically, oven drying at a low heat) to ensure the preservation of their structural integrity. Furthermore, given the propensity for clays to form in highly weathered tropical contexts, it can be a challenge to fully resin-impregnate such fine-grained sediments, resulting in blocks that are not fully resinated and-in the worse case scenariowill disintegrate during cutting (pers. obs.). In this case other methods need to 
be employed, such as the use of a vacuum chamber to draw the resin in to the sediment block.

\section{Geoarchaeological science in Southeast Asia: devising a modus operandi for future research}

Despite the small—but growing—number of useful geoarchaeological studies that do exist, it is clear that the discipline is seriously under-employed in the region. To build up momentum there needs to be a clear strategy for promoting this branch of archaeological science amongst students and heritage professional so that future research forms an integral component of archaeological programs, and from an early stage (Niah Cave is the recent exception) rather than an ad-hoc analysis undertaken at the post-excavation stage.

\subsection{First principles: Steps to be taken to revolutionise the archaeological process in Southeast Asia}

What follows is not intended to be an exhaustive list of steps to be dogmatically adhered to, but rather my personal opinion, with the purpose of stimulating discourse and the exchange of ideas between scientists working in the region. It will probably be noted that some of the points I make below are also relevant to sites in non-tropical regions, but given that geoarchaeology is so scarcely undertaken in this climatic zone it would seem useful to approach this from a common starting point. Ultimately, such guidelines should be compiled into a geoarchaeological manual that can be distributed amongst heritage institutions, commercial units and relevant university departments. I am, of course, not the first person to think about this (see e.g. Anderson, 1997), but what may be novel is the concerted drive to focus purely on how best to do geoarchaeology in the region, and to sow the seeds of a fully-collaborative regional geoarchaeological framework into what I believe is eminently fertile ground for such an endeavour.

\subsubsection{Activities to promote geoarchaeology in the region}

In very broad terms, the following activities would be a useful first step to promote the discipline, preferably undertaken through discussion by a SEA geoarchaeology working group:

- Outreach: promote geoarchaeological research at workshops, seminars, conferences and through online resources (e.g. online geoarchaeological datasets, working groups, SEA archaeology blogs, social media); workshops and seminars would preferably be held at host country institutions where discussion with local archaeologists, apprentice geoarchaeologists and heritage specialists would take place;

- Training: advocate geoarchaeological science to students and heritage professionals in SEA countries, with the aim of highlighting the importance of applying geoarchaeological research to archaeological projects in their respective countries. Some form of apprenticeship/trainee scheme may be an option here (see section on capacity building below); 
- Collaboration: only with fully-collaborative international partnerships will geoarchaeological research really blossom in Southeast Asia. There are countries where these geoarchaeological partnerships are already in place (e.g. Philippines), but a unifying framework and the sharing of ideas might stimulate more of these and help existing ones grow.

\subsubsection{Questions to raise at the early stages of archaeological project planning}

Given that our understanding of tropical geomorphological processes is limited, we should be mindful that geoarchaeological methods and diagnostic signatures with a proven track record in non-tropical zones may not be broadly applicable in the humid tropics. I propose that every archaeological project initiated in the humid tropics should start life as a series of geoarchaeology-driven questions (this of course should be de facto for any archaeological site, regardless of climatic context).

A comprehensive list is beyond the remit of this review, but questions could include:

- Where should excavation trenches be located within a site to minimise the potential of erosion and diagenesis associated with high temperatures and seasonal (monsoonal) groundwater flux?

- What processes deliver sediments to a site and along which pathways, bearing in mind atypical tropical geomorphological processes? Terrestrial sediments in the humid tropics are often locked into deep soils stabilised by dense vegetation, the latter restricting aeolian sediment movement by impeding lateral air-travel. What are the storage times for allogenic sediments in rainforest environments?

- What is the vertical and lateral extent of archaeological contexts and lithological layers? How can the site be broken down into sediment packages that relate to particular modes of deposition (facies)? The effects of diagenesis may blur boundaries between lithological units or create post-depositional changes sedimentary layers.

- Where should samples be taken to maximise the potential of geoarchaeological and palaeoenvironmental data? Tropical caves may have more than a single drip line situated beneath the entrance, there may be driplines from fissures in the roof.

- Given field observations of the general appearance of the site stratigraphy how well preserved is the archaeological material likely to be? Is guano present at the site, and where, and how might this have affected other areas of the site stratigraphy?

Considerations such as these can be deceptively difficult to answer, for both archaeologists and geoarchaeologists. They require not only a great deal of forethought, but command a thorough understanding of geomorphological and geological processes that may be outside the archaeologist's 'comfort zone'. This is even more pertinent when undertaking research in humid tropical environments, which may be a daunting proposition even for a geomorphologist (let alone geoarchaeologist) given that "our knowledge regarding the geomorphology of the tropics remains limited [as] case studies from the tropics 
have hardly been used for generalisation and theory construction" (Gupta, 2011: xiii).

\subsubsection{A holistic approach: (early) dialogue between archaeologists and geoarchaeologists}

What is essential for the future of the discipline in the region is genuine crossdisciplinary collaboration, fostered between geoarchaeologists, archaeologists and other specialists, with early dialogue to avoid geoarchaeological research being relegated to a 'bolt-on' sub-project. A holistic approach needs to be developed so that the geoarchaeologist (or a geoarchaeology trainee) can be onsite during as much of the excavation process as is practicable. This ensures that an understanding of the site can be developed between the archaeologists, geoarchaeologists and technicians, and issues that arise whilst excavating or recording finds and features (e.g. determining the exact location of material relative to complex stratigraphy; interpretation of enigmatic, natural features, such as redox features that can be misinterpreted burning features) can be discussed as they are excavated. In this way, site formation models can be proposed and tested during the crucial fieldwork stages, providing a much more robust and nuanced interpretation of the archaeological record in which all parties can place a good degree of confidence.

\subsection{A 'geoarchaeology manual' for conducting research in the humid tropics}

A set of guidelines for successful geoarchaeological research in tropical Southeast Asia would include procedures and techniques that could be employed to recognise humid tropical site formation processes (section 4.1). It would be beneficial for geoarchaeologists working in these regions to collaborate and share data to achieve this, ideally with the creation of an online repository for geoarchaeological data (e.g. a database of micromorphological images; geochemical spectra obtained from authigenic minerals; physical and chemical attributes of guano). To some greater or lesser extent the geoarchaeology manual that already exists for temperate and tropical zones will have to be assessed and where necessary adapted to accommodate atypical tropical geomorphological processes. The results of data sharing between geoarchaeologists working in the region would form one part of such a manual.

Geoarchaeological techniques that should be employed in future research in the region to elucidate potentially complex site formation processes operating in tropical conditions should include:

- Geochemical mapping of sediments (preferably in thin section to preserve original associations) to quantify the degree of authigenic mineral production (SEM-EDS, FTIR, Raman spectroscopy), with correlation between geochemical and archaeological spatial data;

- Full integration with local and regional palaeoenvironmental datasets;

- Compilation of a micromorphological (microstratigraphic) database of environmentally-diagnostic features that are specific (or modified) in tropical environments;

- On-site geochemical analysis, where applicable, using equipment such as pXRF and $\mu$-FTIR (e.g. Mentzer, 2014) to characterise sediment chemistry 
(e.g. phosphates in guano) and archaeological features (e.g. combustion features);

- Maximise the potential of intact sediment blocks and micromorphological thin sections by undertaking a suite of techniques (e.g. micro-dosimetry for OSL dating, vibrational spectroscopy) on associated materials in laboratory conditions;

- Protocol development for the sampling, recognition and analysis of organic molecules and biomarkers using vibrational spectroscopy and mass spectrometry, and correlation of these data with geoarchaeological data (Flannery, 2016; Luong, 2016).

\section{Capacity Building and Training in Geoarchaeological Science}

Geoarchaeological expertise on-hand during the excavation process can greatly enhance the recording and interpretation process, so it is imperative that geoarchaeological fieldwork skills are developed in host countries to reduce dependence on overseas specialists, an approach that has being trialled successfully on archaeological sites in Lesotho (Arthur et al., 2011; King and Arthur, 2014). Geoarchaeology is very much a field-based discipline, certainly in its initial stages, so there exists genuine potential for training students and local archaeologists in field geoarchaeological techniques. Such an approach has been employed by the author on projects in Southern Africa and Southeast Asia (e.g. Lesotho, Indonesia), by pairing up with a local archaeologist who expresses an interest in learning more about sediments and stratigraphy.

As skills are accrued and confidence builds the 'trainee geoarchaeologist' could attend relevant courses and workshops to build on their field experience and ultimately become specialists in their own right. Students and heritage professionals that may have an interest in landscape archaeology or archaeological site formation processes could step forward from university departments and archaeology institutions in Southeast Asia, many of which have a long history of Palaeolithic archaeological research (e.g. Indonesia, Philippines, Malaysia, and Vietnam). There are likely to be highly trained archaeologists that already have a good understanding of stratigraphy and some knowledge of geoarchaeology who could very easily acquire strong geoarchaeological credentials through collaboration in the field with an existing specialist. Furthermore, many institutes will already have equipment that could be used for off-site geoarchaeological analyses, such as petrological microscopes that are relatively inexpensive.

A set of guidelines for collaborative geoarchaeological fieldwork could be used to help develop a training program, and might also include a step-by-step guide (how to record sediments, how to recognise distinct lithological units, how to recognise natural features, and so forth) used by the trainee when the specialist geoarchaeologist is not on-site. A code of practice for international collaboration in geoarchaeological fieldwork might include the following: 
- Participation in workshops during which a geoarchaeologist introduces geoarchaeological theory and practice to delegates from national heritage bodies, university departments and archaeological institutions;

- Creation of a geoarchaeological apprenticeship scheme, for which a geoarchaeological 'trainee' would work closely with a geoarchaeologist on-site, sharing expertise and experiences. This would take the form of a two-way learning process, as the geoarchaeologist would also learn about the archaeology from an individual trained in that country;

- The trainee and geoarchaeologist would work together on-site to record, sample and carry out provisional field-based interpretations of the sequence, with full explication of the process provided to the trainee;

- This process would eventually lead to the trainee 'graduating' to the position of a 'field geoarchaeologist' with shared responsibility for the geoarchaeological program;

- Ideally this would ultimately lead to the field geoarchaeologist gaining further formal training (e.g. micromorphology workshops; postgraduate studies), and establishing themselves as a fully-trained geoarchaeologist.

\section{Closing Remarks}

The purpose of this review has been two-fold. First, I have attempted to evaluate the geoarchaeological framework of Upper Pleistocene fossil hominin sites and stand-alone geoarchaeological studies from the region, to contextualise the former within a geoarchaeological framework, and showcase the small number of the latter, explaining what in my opinion works well and what could work better. Whilst much of the science from both disciplines is essentially sound, I have-I hope-highlighted the disconnect that often exists between them, and the need for greater collaboration and integration between archaeologists and geoarchaeologists during future work in the region. Second, I have proposed a number of steps that might be taken to advance geoarchaeological science in the region. It has not been my intention to be dogmatic or prescriptive, nor do I consider my proposals to represent the only way to move the discipline forward. What I do want is for this review to act as a catalyst, hopefully nudging forward the process of promoting and practicing geoarchaeology in Southeast Asia, and if this is initiated as dialogue between archaeologists and geoarchaeologists in the region then I think that it may have served its purpose in some small way.

The crux of the matter is that in Southeast Asia there is a rich and important archaeological record that tracks the movement of our species into and out of the region over the past 100,000 years or more. A scientifically rigorous geoarchaeological framework is required to fully contextualise this material, both in terms of its precise stratigraphic location and the environmental history of the sediments from which it was recovered. If we can develop this geoarchaeological framework and employ it at an early stage (or even in advance) of archaeological planning then it could be employed as a predictive tool, affording the targeting of specific areas of the site sequence that have the best chance of containing and preserving archaeological and skeletal material. Such a targeted approach has the added benefit of potentially averting large 
1 costs related to sinking excavation trenches at random across a site, which can

2 represent a significant drain on all too precious research funds.

Disentangling the archaeological and palaeoanthropological record of the region really is a grand challenge, and one that requires increased collaboration between specialists in the region, the promotion of geoarchaeological science, and an increase in the capacity for countries of the region to undertake their own geoarchaeological research. To do this what we need first and foremost are new sites to fill the significant geographic and intellectual gaps in our understanding of the colonisation of Southeast Asia by early modern humans.

\section{Acknowledgements}

The impetus behind this review was a conference paper delivered at the Australian Archaeological Association's (AAA) annual meeting, Cairns, in December 2014. I should like to extend my thanks to Robin Torrence, whose enthusiasm for that paper spurred me on to write this review and conceive the idea for the Geoarchaeology in the Humid Tropics Special Issue of JAS. I would like to thank Bert Roberts and the rest of the research group at the University of Wollongong for the chance to work on these research projects. Special thanks go to Matthew Tocheri, Paul Goldberg and Alex Mackay who commented on early drafts of this paper and whose comments contributed greatly to the final outcome of this paper. Discussions with Conor Mcadams about bat guano did much to focus certain elements of this review. Finally, I thank Ania KotarbaMorley for her astute editorial advice, invaluable discussions regarding key aspects of the research, and unending patience. 


\section{REFERENCES}

Allen, J., \& O'Connell, J. F. (2008). Getting from Sunda to Sahul. Islands of inquiry: Colonisation, seafaring and the archaeology of maritime landscapes, 31-46.

Anderson, D. D. (1997). Cave archaeology in Southeast Asia. Geoarchaeology, 12(6), 607-638.

Araujo, A. G., Feathers, J. K., Arroyo-Kalin, M., \& Tizuka, M. M. (2008). Lapa das Boleiras rockshelter: stratigraphy and formation processes at a Paleoamerican site in Central Brazil. Journal of Archaeological Science, 35(12), 3186-3202.

Araujo, A. G. M., \& Marcelino, J. C. (2003). The role of armadillos in the movement of archaeological materials: an experimental approach. Geoarchaeology, 18(4), 433-460.

Armitage, S. J., Jasim, S. A., Marks, A. E., Parker, A. G., Usik, V. I., \& Uerpmann, H. P. (2011). The southern route "Out of Africa": evidence for an early expansion of modern humans into Arabia. Science, 331(6016), 453-456.

Arthur, C., Mohapi, M., \& Mitchell, P. (2011). Archaeology and dam projects in Lesotho. Conservation and Management of Archaeological Sites, 13(2-3), 231-252.

Aubert, M., Brumm, A., Ramli, M., Sutikna, T., Saptomo, E. W., Hakim, B., \& Dosseto, A. (2014). Pleistocene cave art from Sulawesi, Indonesia. Nature, 514 (7521), 223-227.

Bacon, A. M., Demeter, F., Roussé, S., Long, V. T., Duringer, P., Antoine, P. O., \& Matsumura, H. (2006). New palaeontological assemblage, sedimentological and chronological data from the Pleistocene Ma U'Oi cave (northern Vietnam). Palaeogeography, Palaeoclimatology, Palaeoecology, 230(3), 280-298.

Bacon, A. M., Demeter, F., Duringer, P., Helm, C., Bano, M., Long, V. T., \& Dodo, Y. (2008). The Late Pleistocene Duoi U'Oi cave in northern Vietnam: palaeontology, sedimentology, taphonomy and palaeoenvironments. Quaternary Science Reviews, 27(15), 1627-1654.

Bacon, A. M., Westaway, K., Antoine, P. O., Duringer, P., Blin, A., Demeter, F., \& Thuy, N. T. K. (2015). Late Pleistocene mammalian assemblages of Southeast Asia: New dating, mortality profiles and evolution of the predator-prey relationships in an environmental context. Palaeogeography, Palaeoclimatology, Palaeoecology, 422, 101-127.

Bae, C. J., Wang, W., Zhao, J., Huang, S., Tian, F., \& Shen, G. (2014). Modern human teeth from Late Pleistocene Luna Cave (Guangxi, China). Quaternary International, 354, 169-183. 
Bailey, R. C., Head, G., Jenike, M., Owen, B., Rechtman, R., \& Zechenter, E. (1989). Hunting and gathering in tropical rain forests: Is it possible?. American Anthropologist, 91(1), 59-82.

Bar-Yosef, O., \& Wang, Y. (2012). Paleolithic archaeology in China. Annual Review of Anthropology, 41, 319-335.

Barker, G. (Ed.). (2013). Rainforest foraging and farming in Island Southeast Asia. The Archaeology of the Niah Caves, Volume 1. McDonald Institute Monographs. Cambridge: McDonald Institute of Archaeological Research.

Barker, G. (Ed.). (2016). Archaeological Investigations in the Niah Caves, Sarawak. The Archaeology of the Niah Caves, Volume 2. McDonald Institute Monographs. Cambridge: McDonald Institute of Archaeological Research.

Barker, G., Barton, H., Bird, M., Daly, P., Datan, I., Dykes, A., Farr, L., Gilbertson, D., Harrisson, B., Hunt, C. \& Higham, T. (2007). The 'human revolution' in lowland tropical Southeast Asia: the antiquity and behaviour of anatomically modern humans at Niah Cave (Sarawak, Borneo). Journal of Human Evolution, 52 (3), 243-261.

Bellwood, P. (2014). First migrants: ancient migration in global perspective. UK; John Wiley \& Sons.

Bird, M. I., Taylor, D., \& Hunt, C. (2005). Palaeoenvironments of insular Southeast Asia during the Last Glacial Period: a savanna corridor in Sundaland?. Quaternary Science Reviews, 24 (20), 2228-2242.

Bird, M. I., Boobyer, E. M., Bryant, C., Lewis, H. A., Paz, V., \& Stephens, W. E. (2007). A long record of environmental change from bat guano deposits in Makangit Cave, Palawan, Philippines. Earth and Environmental Science Transactions of the Royal Society of Edinburgh, 98 (01), 59-69.

Birdsell, J. B. (1977). The recalibration of a paradigm for the first peopling of greater Australia. Sunda and Sahul: Prehistoric Studies in Southeast Asia, Melanesia, and Australia., 113-167.

Boivin, N., Fuller, D. Q., Dennell, R., Allaby, R., \& Petraglia, M. D. (2013). Human dispersal across diverse environments of Asia during the Upper Pleistocene. Quaternary International, 300, 32-47.

Bowler, J. M. Johnston, H., Olley, J.M., Prescott, J.R., Roberts, R.G., Shawcross, W., \& Spooner, N.A. (2003). New ages for human occupation and climatic change at Lake Mungo, Australia. Nature 421, 837-840.

Brain, C. K. (1983). The hunters or the hunted?: an introduction to African cave taphonomy. University of Chicago Press. 
Canti, M., \& Huisman, D. J. (2015). Scientific advances in geoarchaeology during the last twenty years. Journal of Archaeological Science, 56, 96-108.

Chase, D. Z., Chase, A. F., Awe, J. J., Walker, J. H., \& Weishampel, J. F. (2011). Airborne LiDAR at Caracol, Belize and the interpretation of ancient Maya society and landscapes. Research Reports in Belizean Archaeology, 8, 61-73.

Choa, O., Lebon, M., Gallet, X., Dizon, E., Ronquillo, W., Jago-on, S. C., \& Sémah, F. (2016). Stable isotopes in guano: Potential contributions towards palaeoenvironmental reconstruction in Tabon Cave, Palawan, Philippines. Quaternary International.

Clarkson, C., Smith, M., Marwick, B., Fullagar, R., Wallis, L.A., Faulkner, P., Manne, T., Hayes, E., Roberts, R.G., Jacobs, Z., \& Carah, X. (2015). The archaeology, chronology and stratigraphy of Madjedbebe (Malakunanja II): A site in northern Australia with early occupation. Journal of Human Evolution, 83, 46-64.

Corlett, R. T. (2014). The ecology of tropical East Asia. Oxford University Press (UK).

Curnoe, D., Xueping, J., Herries, A. I., Kanning, B., Taçon, P. S., Zhende, B., \& Cassis, G. (2012). Human remains from the Pleistocene-Holocene transition of southwest China suggest a complex evolutionary history for East Asians. PLoS One, 7(3), e31918.

Curnoe, D., Ji, X., Taçon, P. S., \& Yaozheng, G. (2015). Possible signatures of hominin hybridization from the early Holocene of Southwest China. Scientific reports, 5.

Demeter, F., Shackelford, L. L., Bacon, A. M., Duringer, P., Westaway, K., Sayavongkhamdy, T., \& Karpoff, A. M. (2012). Anatomically modern human in Southeast Asia (Laos) by $46 \mathrm{ka}$. Proceedings of the National Academy of Sciences, 109(36), 14375-14380.

Demeter, F., Shackelford, L. L., Westaway, K. E., Duringer, P., Sayavongkhamdy, T., \& Bacon, A. M. (2012b). Reply to Pierret et al.: Stratigraphic and dating consistency reinforces the status of Tam Pa Ling fossil. Proceedings of the National Academy of Sciences, 109(51), E3524-E3525.

Demeter, F., Shackelford, L., Westaway, K., Duringer, P., Bacon, A. M., Ponche, J. L., $\mathrm{Wu}, \mathrm{X}$., Sayavongkhamady, T., Zhao, J-X., Barnes, L., Boyon, M., Sichanthongtip, P., Senegas, F., Karpoff, A-M., Patole-Edoumba, E., Coppen, Y., \& Braga, J. (2015). Early modern humans and morphological variation in Southeast Asia: fossil evidence from Tam Pa Ling, Laos. PLoS One, 10 (4), e0121193.

Dennell, R. (2008). The Palaeolithic settlement of Asia. UK: Cambridge University Press. 
Dennell, R. (2010). Palaeoanthropology: Early Homo sapiens in China. Nature, 468 (7323), 512-513.

Dennell, R. (2014). Smoke and mirrors: the fossil record for Homo sapiens between Arabia and Australia. In: Dennell, R, \& Porr, M. (Eds.), Southern Asia, Australia and the search for human origins. Cambridge: Cambridge University Press. $p$, 33-50.

Dennell, R. W., Louys, J., O'Regan, H. J., \& Wilkinson, D. M. (2014). The origins and persistence of Homo floresiensis on Flores: biogeographical and ecological perspectives. Quaternary Science Reviews, 96, 98-107.

Dennell, R. (2015). Asian Palaeolithic dispersals. In, Christian, D. (Ed.) The Cambridge World History, Volume 1, pp. 414-432. Cambridge: Cambridge University Press.

Dennell, R., \& Petraglia, M. D. (2012). The dispersal of Homo sapiens across southern Asia: how early, how often, how complex? Quaternary Science Reviews, 47, 15-22.

Dennell, R. W., Louys, J., O'Regan, H. J., \& Wilkinson, D. M. (2014). The origins and persistence of Homo floresiensis on Flores: biogeographical and ecological perspectives. Quaternary Science Reviews, 96, 98-107.

Détroit, F., Dizon, E., Falguères, C., Hameau, S., Ronquillo, W., \& Sémah, F. (2004). Upper Pleistocene Homo sapiens from the Tabon cave (Palawan, The Philippines): description and dating of new discoveries. Comptes Rendus Palevol, 3(8), 705-712.

Dizon, E., Détroit, F., Sémah, F., Falguères, C., Hameau, S., Ronquillo, W., \& Cabanis, E. (2002). Notes on the morphology and age of the Tabon Cave fossil Homo sapiens. Current Anthropology, 43 (4), 660-666.

Duringer, P., Bacon, A. M., Sayavongkhamdy, T., \& Nguyen, T. K. T. (2012). Karst development, breccias history, and mammalian assemblages in Southeast Asia: A brief review. Comptes Rendus Palevol, 11(2), 133-157.

Dykes, A. P. (2007). Mass movements in cave sediments: investigation of a 40,000-year-old guano mudflow inside the entrance of the Great Cave of Niah, Sarawak, Borneo. Landslides, 4(3), 279-290.

Faylona, M. G. P. G., Lazareth, C. E., Sémah, A. M., Caquineau, S., Boucher, H., \& Ronquillo, W. P. (2011). Preliminary study on the preservation of giant clam (Tridacnidae) shells from the Balobok Rockshelter archaeological site, South Philippines. Geoarchaeology, 26(6), 888-901. 
Flannery, E. (2016). Surviving the tropics: challenges in organic residue analysis. The Archaeology of Liang Bua, Flores: Interdisciplinary Research and Future Research Directions, 7-11 March, 2016. Jakarta, Indonesia.

Ford, D., and Williams, P. D. (2007). Karst Hydrogeology and Geomorphology. John Wiley \& Sons.

Fox, R. B. (1970). The Tabon Caves: archaeological explorations and excavations on Palawan Island, Philippines. National Museum of Philippines Monograph, No. 1.

Gatti, E., Villa, I. M., Achyuthan, H., Gibbard, P. L., \& Oppenheimer, C. (2014). Geochemical variability in distal and proximal glass from the Youngest Toba Tuff eruption. Bulletin of Volcanology, 76(9), 1-16.

Gao, X., \& Norton, C. J. (2002). A critique of the Chinese 'Middle Palaeolithic'. Antiquity, 76(292), 397-412.

Gibbons, A. (2015). Prehistoric Eurasians streamed into Africa, genome shows. Science, 350(6257), 149-149.

Gilbertson, D., Bird, M., Hunt, C., McLaren, S., Banda, R. M., Pyatt, B., Rose, J., \& Stephens, M. (2005). Past human activity and geomorphological change in a guano-rich tropical cave mouth: initial interpretations of the Late Quaternary succession in the Great Cave of Niah, Sarawak. Asian Perspectives, 16-41.

Gillieson, D. (1986). Cave sedimentation in the New Guinea highlands. Earth Surface Processes and Landforms, 11(5), 533-543.

Glover, I. C. (1979). The effects of sink action on archaeological deposits in caves: an Indonesian example. World Archaeology, 10 (3), 302-317.

Goldberg, P., \& Nathan, Y. (1975). The phosphate mineralogy of et-Tabun cave. Mineralogical Magazine, 40: 253-258.

Goldberg, P., \& Sherwood, S. C. (2006). Deciphering human prehistory through the geoarcheological study of cave sediments. Evolutionary Anthropology: Issues, News, and Reviews, 15(1), 20-36.

Goldberg, P., \& Macphail, R. I. (2008). Practical and Theoretical Geoarchaeology. Blackwell publishing.

Goldberg, P., \& Berna, F. (2010). Micromorphology and context. Quaternary International, 214(1), 56-62.

Groucutt, H. S., Petraglia, M. D., Bailey, G., Scerri, E. M., Parton, A., Clark-Balzan, L., Jennings, R.P., Lewis, L., Blinkhorn, J., Drake, N.A., Breeze, P.S., Inglis, R.H., Deves, M.H., Meredith-Williams, M., Boivin, N., Thomas, M.G. \& Scally, A. 
(2015). Rethinking the dispersal of Homo sapiens out of Africa. Evolutionary Anthropology: Issues, News, and Reviews, 24 (4), 149164.

Grün, R., \& Stringer, C. B. (1991). Electron spin resonance dating and the evolution of modern humans. Archaeometry, 33(2), 153-199.

Gupta, A. (1993). The changing geomorphology of the humid tropics. Geomorphology, 7(1-3), 165-186.

Gupta, A. (2011). Tropical geomorphology. Cambridge: Cambridge University Press.

Higham, C. (2014). Early Mainland Southeast Asia. Bangkok: River Books.

Hiscock, P., 2015. Cultural diversification and the global dispersion of Homo sapiens: lessons from Australia. In: Kaifu, Y., Izuho, M., Goebel, T., Sato, H., Ono, A. (Eds), Emergence and Diversity of Modern Human Behaviour in Paleolithic Asia, pp. 225-236. Texas A\&M University Press, College Station.

Hunt, C. O., \& Rushworth, G. (2005). Cultivation and human impact at $6000 \mathrm{cal}$ yr BP in tropical lowland forest at Niah, Sarawak, Malaysian Borneo. Quaternary Research, 64(3), 460-468.

Hunt, C. O., Gilbertson, D. D., \& Rushworth, G. (2012). A 50,000-year record of late Pleistocene tropical vegetation and human impact in lowland Borneo. Quaternary Science Reviews, 37, 61-80.

Hunt, C. O., Gilbertson, D. D., Hill, E. A., \& Simpson, D. (2015). Sedimentation, resedimentation and chronologies in archaeologically-important caves: problems and prospects. Journal of Archaeological Science, 56, 109-116.

Jones, S. E., Barton, H., Hunt, C. O., Janowski, M., Lloyd-Smith, L., \& Barker, G. (2015). The cultural antiquity of rainforests: Human-plant associations during the mid-late Holocene in the interior highlands of Sarawak, Malaysian Borneo. Quaternary International. In press.

Karkanas, P., Bar-Yosef, O., Goldberg, P., \& Weiner, S. (2000). Diagenesis in prehistoric caves: the use of minerals that form in situ to assess the completeness of the archaeological record. Journal of Archaeological Science, 27(10), 915-929.

Karkanas, P., \& Goldberg, P. (2010). Site formation processes at Pinnacle point Cave 13B (Mossel Bay, Western Cape Province, South Africa): resolving stratigraphic and depositional complexities with micromorphology. Journal of Human Evolution, 59(3), 256-273. 
Karkanas, P., \& Goldberg, P. (2010). Phosphatic Features. In: Stoops, G. \& Mees, F. (Eds.), Interpretation of Micromorphological Features of Soils and Regoliths (pp. 521-541). Elsevier B.V.

Karkanas, P., Rigaud, J. P., Simek, J. F., Albert, R. M., \& Weiner, S. (2002). Ash bones and guano: a study of the minerals and phytoliths in the sediments of Grotte XVI, Dordogne, France. Journal of Archaeological Science, 29(7), 721-732.

Karkanas, P., Schepartz, L. A., Miller-Antonio, S., Wang, W., \& Huang, W. (2008). Late Middle Pleistocene climate in southwestern China: inferences from the stratigraphic record of Panxian Dadong Cave, Guizhou. Quaternary Science Reviews, 27(15-16), 1555-1570.

King, R., \& Arthur, C. (2014). Development-led archaeology and ethics in Lesotho. Azania: Archaeological Research in Africa, 49(2), 166-183.

Köppen, W. (1923). Die Klimate der Erde: Grundriss der Klimakunde. Walter de Gruyter \& Company.

Kourampas, N., Simpson, I. A., Perera, N., Deraniyagala, S. U., \& Wijeyapala, W. H. (2009). Rockshelter sedimentation in a dynamic tropical landscape: Late Pleistocene-Early Holocene archaeological deposits in Kitulgala Beli-lena, southwestern Sri Lanka. Geoarchaeology, 24(6), 677-714.

Kourampas, N., Shipton, C., Mills, W., Tibesasa, R., Horton, H., Horton, M., \& Picornell, L. (2015). Late Quaternary speleogenesis and landscape evolution in a tropical carbonate island: Pango la Kuumbi (Kuumbi Cave), Zanzibar. International Journal of Speleology, 44(3), 293.

Kuhlwilm, M., Gronau, I., Hubisz, M. J., de Filippo, C., Prado-Martinez, J., Kircher, M., \& Rosas, A. (2016). Ancient gene flow from early modern humans into Eastern Neanderthals. Nature, 530(7591), 429-433.

Lambeck, K., \& Chappell, J. (2001). Sea level change through the last glacial cycle. Science, 292 (5517), 679-686.

Lewis, H. (2003). The potential of soil micromorphology in Southeast Asian archaeology: Preliminary work at Niah Cave Sarawak, Malaysia, and Ille Cave, Palawan, Philippines. Hukay. Journal of the University of the Philippines Archaeological Studies Program, 5, 60-72.

Lewis, H. (2007). Preliminary soil micromorphology studies of landscape and occupation history at Tabon Cave, Palawan, Philippines. GeoarchaeologyAn International Journal. 22(7), 685.

Lewis, H., Johnson, K., \& Ronquillo, W. (2008). Preliminary results of speleothem dating from Tabon Cave, Palawan, Philippines: moisture increase at the Last Glacial Maximum. Hukay, 12. 
Liu, W., Jin, C. Z., Zhang, Y. Q., Cai, Y. J., Xing, S., Wu, X. J., \& An, Z. S. (2010). Human remains from Zhirendong, South China, and modern human emergence in East Asia. Proceedings of the National Academy of Sciences, 107(45), 19201-19206.

Liu, W., Martinón-Torres, M., Cai, Y. J., Xing, S., Tong, H. W., Pei, S. W., \& Wu, X. J. (2015). The earliest unequivocally modern humans in southern China. Nature 526: 696-699.

Llorente, M. G., Jones, E. R., Eriksson, A., Siska, V., Arthur, K. W., Arthur, J. W., ... \& Stretton, S. (2015). Ancient Ethiopian genome reveals extensive Eurasian admixture throughout the African continent. Science, 350(6262), 820-822.

Long, T., de Vos, J., \& Ciochon, R. L. (1996). The fossil mammal fauna of the Lang Trang caves, Vietnam, compared with Southeast Asian fossil and recent mammal faunas: the geographical implications. Bulletin of the Indo-Pacific Prehistory Association, 14, 101-109.

Luong, S. (2016). Residue identification using mass spectrometry. The Archaeology of Liang Bua, Flores: Interdisciplinary Research and Future Research Directions, 7-11 March, 2016. Jakarta, Indonesia.

Maeght, J. L., Rewald, B., \& Pierret, A. (2013). How to study deep roots-and why it matters. Frontiers in plant science, 4.

Marwick, B. (2009). Biogeography of Middle Pleistocene hominins in mainland Southeast Asia: A review of current evidence. Quaternary International, 202(1), 51-58.

McDougall, I., Brown, F. H., \& Fleagle, J. G. (2005). Stratigraphic placement and age of modern humans from Kibish, Ethiopia. Nature, 433(7027), 733736.

Macintosh, N. W. G., \& Barker, B. C. W. (1978). The Tabon cave mandible. Archaeology and Physical Anthropology in Oceania, 13(2-3), 143-166.

Mellars, P. (2006). Why did modern human populations disperse from Africa ca. 60,000 years ago? A new model. Proceedings of the National Academy of Sciences, 103(25), 9381-9386.

Mellars, P., Gori, K. C., Carr, M., Soares, P. A., \& Richards, M. B. (2013). Genetic and archaeological perspectives on the initial modern human colonization of southern Asia. Proceedings of the National Academy of Sciences, 110(26), 10699-10704.

Mentzer, S. M. (2014). Microarchaeological approaches to the identification and interpretation of combustion features in prehistoric archaeological sites. Journal of Archaeological Method and Theory, 21(3), 616-668. 
Mercader, J. (2002). Forest people: The role of African rainforests in human evolution and dispersal. Evolutionary Anthropology: Issues, News, and Reviews, 11(3), 117-124.

Mercader, J. (2002). Under the canopy: the archaeology of tropical rain forests. Rutgers: University Press.

Mercader, J., Martı, R., González, I. J., Sánchez, A., \& Garcıa, P. (2003). Archaeological site formation in rain forests: insights from the Ituri rock shelters, Congo. Journal of Archaeological Science, 30(1), 45-65.

Mijares, A. S. B., \& Lewis, H. A. (2009). Cave sites in northeastern Luzon, Philippines: A preliminary soil micromorphological study. Asian Perspectives, 48 (1), 98-118.

Mijares, A. S., Détroit, F., Piper, P., Grün, R., Bellwood, P., Aubert, M., \& Dizon, E. (2010). New evidence for a 67,000-year-old human presence at Callao Cave, Luzon, Philippines. Journal of human evolution, 59(1), 123-132.

Miller, C.E., Goldberg, P., \& Berna, F. (2013). Geoarchaeological investigations at Diepkloof Rock Shelter, Western Cape, South Africa. Journal of Archaeological Science, 40(9), 3432-3452.

Morley, M. W., \& Woodward, J. C. (2011). The Campanian Ignimbrite (Y5) tephra at Crvena Stijena Rockshelter, Montenegro. Quaternary Research,75(3), 683-696.

Morley, M. W., Goldberg, P., Sutikna, T., Tocheri, M. W., Prinsloo, L. C., Jatmiko, Saptomo, E. W., Wasisto, S., \& Roberts, R. G. (2016). Initial micromorphological results from Liang Bua, Flores (Indonesia): site formation processes and hominin activities at the type locality of Homo floresiensis. Journal of Archaeological Science. In Review.

Morwood, M.J, Soejono, R.P., Roberts, R.G., Sutikna, T., Turney, C.S.M., Westaway, K.E., Rink, W.J., Zhao, J.X., van den Bergh, G.D., Due, R.A., Hobbs, D.R., Moore, M.W., Bird, M.I., and Fifield, L.K. (2004). Archaeology and age of a new hominin from Flores in eastern Indonesia. Nature, 431:1087-1091.

Morwood M.J., Brown P., Jatmiko, Sutikna T., Saptomo E.W., Westaway K.E., Due R.A., Roberts R.G., Maeda T., Wasisto S., and Djubiantono T. (2005). Further evidence for small-bodied hominins from the Late Pleistocene of Flores, Indonesia. Nature, 437:1012-1017.

Mudar, K., \& Anderson, D. (2007). New evidence for Southeast Asian Pleistocene foraging economies: faunal remains from the early levels of Lang Rongrien rockshelter, Krabi, Thailand. Asian Perspectives, 298-334. 
O'Connell, J. F., Allen, J., \& Hawkes, K. (2010). Pleistocene Sahul and the origins of seafaring. In: Anderson, A., Barrett, J. H., \& Boyle, K. V. (Eds), The global origins and development of seafaring, pp. 57-68. Cambridge: McDonald Institute of Archaeological Research.

O'Connell, J.F. \& Allen, J. (2015). The process, biotic impact, and global implications of the human colonization of Sahul about 47,000 years ago. Journal of Archaeological Science, 56, 73-84

O'Connor, S. (2007). New evidence from East Timor contributes to our understanding of earliest modern human colonisation east of the Sunda Shelf. Antiquity 81, 523-535.

O'Connor, S. (2015). Crossing the Wallace Line: the maritime skills of the earliest colonists in the Wallacean Archipelago. In: Kaifu, Y., Izuho, M., Goebel, T., Sato, H., \& Ono, A. (Eds), Emergence and Diversity of Modern Human Behaviour in Paleolithic Asia, pp. 214-224. Texas A\&M Univ. Press, College Station.

O'Connor, S., Ono, R., \& Clarkson, C. (2011). Pelagic fishing at 42,000 years before the present and the maritime skills of modern humans. Science, 334, 1117-1121.

Pääbo, S. (2014). The human condition—a molecular approach. Cell, 157(1), 216226.

Pääbo, S. (2015). The diverse origins of the human gene pool. Nature Reviews Genetics, 16(6), 313-314.

Pawlik, A. F., Piper, P. J., \& Mijares, A. S. B. (2014). Modern Humans in the Philippines: Colonization, Subsistence and New Insights into Behavioural Complexity. Southern Asia, Australia and the search for Human Origins, 135-47.

Perera, N., Kourampas, N., Simpson, I. A., Deraniyagala, S. U., Bulbeck, D., Kamminga, J., ... \& Oliveira, N. V. (2011). People of the ancient rainforest: Late Pleistocene foragers at the Batadomba-lena rockshelter, Sri Lanka. Journal of human evolution, 61(3), 254-269.

Petraglia, M., Korisettar, R., Boivin, N., Clarkson, C., Ditchfield, P., Jones, S., ... \& Roberts, R. (2007). Middle Paleolithic assemblages from the Indian subcontinent before and after the Toba super-eruption. Science, 317(5834), 114-116.

Petraglia, M. D., Ditchfield, P., Jones, S., Korisettar, R., \& Pal, J. N. (2012). The Toba volcanic super-eruption, environmental change, and hominin occupation history in India over the last 140,000 years. Quaternary International, 258, 119-134. 
Pierret, A., Zeitoun, V., \& Forestier, H. (2012). Irreconcilable differences between stratigraphy and direct dating cast doubts upon the status of Tam Pa Ling fossil. Proceedings of the National Academy of Sciences, 109(51), E3523E3523.

Rabett, R. J., Piper, P. J., \& Barker, G. (2006). Bones from Hell: Preliminary results of new work on the Harrisson faunal assemblage from the deepest part of Niah Cave, Sarawak. Uncovering Southeast Asia's Past, 46-59.

Piper, P. J., \& Rabett, R. J. (2009). Disentangling the Harrisson archive to interpret the spatial and temporal distribution of vertebrate remains at Niah Caves, Sarawak. International Journal of Osteoarchaeology, 19(4), 464-475.

Pookajorn, S. (1996). Human activities and environmental changes during the late Pleistocene to middle Holocene in southern Thailand and Southeast Asia (pp. 201-213). Springer US.

Rabett, R. J. (2012). Human Adaptation in the Asian Palaeolithic. Cambridge: Cambridge University Press.

Rabett, R., Appleby, J., Blyth, A., Farr, L., Gallou, A., Griffiths, T., Hawkes, J., Marcus, D., Marlow, L., Morley, M. W., Tân, N. C., Son, N. V. (2011). Inland shell midden site-formation: Investigation into a late Pleistocene to early Holocene midden from Tràng An, Northern Vietnam. Quaternary International, 239(1), 153-169.

Reyes-Centeno, H., Hubbe, M., Hanihara, T., Stringer, C., \& Harvati, K. (2015). Testing modern human out-of-Africa dispersal models and implications for modern human origins. Journal of Human Evolution, 87, 95-106.

Roberts, P., Perera, N., Wedage, O., Deraniyagala, S., Perera, J., Eregama, S., ... \& Lee-Thorp, J. A. (2015). Direct evidence for human reliance on rainforest resources in late Pleistocene Sri Lanka. Science, 347(6227), 1246-1249.

Roberts, R.G., Jones, R., Smith, M.A., (1990). Thermoluminescence dating of a 50,000-year-old human occupation site in northern Australia. Nature, 345, 153-156.

Roberts, R. G., Jones, R., Spooner, N. A., Head, M. J., Murray, A. S., \& Smith, M. A. (1994). The human colonisation of Australia: optical dates of 53,000 and 60,000 years bracket human arrival at Deaf Adder Gorge, Northern Territory. Quaternary Science Reviews, 13(5), 575-583.

Roberts, P., \& Petraglia, M. (2015). Pleistocene rainforests: barriers or attractive environments for early human foragers?. World Archaeology, 47(5), 718739.

Roberts, P., Boivin, N., \& Petraglia, M. (2015). The Sri Lankan 'Microlithic'Tradition c. 38,000 to 3,000 Years Ago: Tropical Technologies 
and Adaptations of Homo sapiens at the Southern Edge of Asia. Journal of World Prehistory, 28(2), 69-112.

Rose, J. I., Usik, V. I., Marks, A. E., Hilbert, Y. H., Galletti, C. S., Parton, A., \& Roberts, R. G. (2011). The Nubian complex of Dhofar, Oman: an African middle stone age industry in southern Arabia. PLoS One, 6(11), e28239.

Schepartz, L. A., Miller-Antonio, S., \& Bakken, D. A. (2000). Upland resources and the early Palaeolithic occupation of southern China, Vietnam, Laos, Thailand and Burma. World Archaeology, 32(1), 1-13.

Schiegl, S., Goldberg, P., Bar-Yosef, O., \& Weiner, S. (1996). Ash deposits in Hayonim and Kebara caves, Israel: macroscopic, microscopic and mineralogical observations, and their archaeological implications. Journal of archaeological Science, 23(5), 763-781.

Schiffer, M. B. (1972). Archaeological context and systemic context. American Antiquity, 156-165.

Schiffer, M. B. (1987). Formation processes of the archaeological record. USA: University of Utah Press.

Self, S., \& Gertisser, R. (2015). Tying down eruption risk. Nature Geoscience, 8(4), 248-250.

Shahack-Gross, R., Berna, F., Karkanas, P., \& Weiner, S. (2004). Bat guano and preservation of archaeological remains in cave sites. Journal of Archaeological Science, 31(9), 1259-1272.

Shen, G., Wang, W., Wang, Q., Zhao, J., Collerson, K., Zhou, C., \& Tobias, P. V. (2002). U-Series dating of Liujiang hominid site in Guangxi, Southern China. Journal of Human Evolution, 43 (6), 817-829.

Stephens, M., Rose, J., Gilbertson, D. D., \& Canti, M. G. (2005). Micromorphology of Cave Sediments in the Humid Tropics: Niah Cave, Sarawak. Asian Perspectives 44(1), 42-55. University of Hawaii Press.

Stephens, M., Rose, J., \& Gilbertson, D. D. (2016). Post-depositional alteration of humid tropical cave sediments: Micromorphological research in the Great Cave of Niah, Sarawak, Borneo. Journal of Archaeological Science (online, in press).

Stiner, M. C., Kuhn, S. L., Surovell, T. A., Goldberg, P., Meignen, L., Weiner, S., \& Bar-Yosef, O. (2001). Bone preservation in Hayonim Cave (Israel): a macroscopic and mineralogical study. Journal of Archaeological Science, $28(6), 643-659$. 
Stringer, C. B. (1989). The origin of early modern humans: a comparison of the European and non-European evidence. The Human Revolution. Princeton University Press, Princeton, 232-244.

Stringer, C. (2000). Palaeoanthropology: coasting out of Africa. Nature, 405(6782), 24-27.

Storm, P., Aziz, F., de Vos, J., Kosasih, D., Baskoro, S., \& van den Hoek Ostende, L. W. (2005). Late Pleistocene Homo sapiens in a tropical rainforest fauna in East Java. Journal of Human Evolution, 49 (4), 536-545.

Storm, P., Wood, R., Stringer, C., Bartsiokas, A., de Vos, J., Aubert, M., Kinsley, L., \& Grün, R. (2013). U-series and radiocarbon analyses of human and faunal remains from Wajak, Indonesia. Journal of Human Evolution, 64 (5), 356365.

Stringer, C. B. (1989). The origin of early modern humans: a comparison of the European and non-European evidence. The Human Revolution. Princeton University Press, Princeton, 232-244.

Summerhayes, G. R., Leavesley, M., Fairbairn, A., Mandui, H., Field, J., Ford, A., \& Fullagar, R. (2010). Human adaptation and plant use in highland New Guinea 49,000 to 44,000 years ago. Science, 330(6000), 78-81.

Summerhayes, G. R., Field, J. H., Shaw, B., \& Gaffney, D. (2016). The archaeology of forest exploitation and change in the tropics during the Pleistocene: The case of Northern Sahul (Pleistocene New Guinea). Quaternary International.

Sutikna, T., Tocheri, M. W., Morwood, M. J., Saptomo, E. W., Jatmiko, Due, R. A., Wasisto, S., Westaway, K. E., Aubert, M., Li, B., Zhao, J.-x., Storey, M., Alloway, B. V., Morley, M. W., Meijer, H. J. M., van den Bergh, G. D., Grün, R., Dosseto, A., Brumm, A., Jungers, W. L., Roberts, R. G. (2016). Revised stratigraphy and chronology for Homo floresiensis at Liang Bua in Indonesia. Nature. 532: 366-369.

Szabó, K., \& Amesbury, J. R. (2011). Molluscs in a world of islands: The use of shellfish as a food resource in the tropical island Asia-Pacific region. Quaternary International, 239(1), 8-18.

van den Bergh, G. D., Meijer, H. J. M., Awe, R. D., Morwood, M. J., Szabó, K., van den Hoek Ostende, L. W., Sutikna, T., Saptomo, E. W., Piper, P. J. \& Dobney, K. M. (2009). The Liang Bua faunal remains: a 95k. yr. sequence from Flores, East Indonesia. Journal of Human Evolution, 57(5), pp.527-537.

van den Bergh, G. D., Li, B., Brumm, A., Grün, R., Yurnaldi, D., Moore, M. W., \& Storey, M. (2016). Earliest hominin occupation of Sulawesi, Indonesia. Nature, 529(7585), 208-211. 
Voris, H. K. (2000). Maps of Pleistocene sea levels in Southeast Asia: shorelines, river systems and time durations. Journal of Biogeography, 27(5), 11531167.

Weiner, S. (2010). Microarchaeology: beyond the visible archaeological record. Cambridge University Press.

Weiner, S., Goldberg, P., \& Bar-Yosef, O. (2002) Three-dimensional distribution of minerals in the sediments of Hayonim Cave, Israel: Diagenetic processes and archaeological implications. Journal of Archaeological Science, 29, 1289-1308.

Westaway, K. E., Morwood, M. J., Roberts, R. G., Rokus, A. D., Zhao, J. X., Storm, P., \& De Vos, J. (2007). Age and biostratigraphic significance of the Punung Rainforest Fauna, East Java, Indonesia, and implications for Pongo and Homo. Journal of Human Evolution, 53(6), 709-717.

Westaway, K. E., Sutikna, T., Saptomo, W. E., Morwood, M. J., Roberts, R. G., \& Hobbs, D. R. (2009b). Reconstructing the geomorphic history of Liang Bua, Flores, Indonesia: a stratigraphic interpretation of the occupational environment. Journal of Human Evolution, 57(5), 465-483.

White, T. D., Asfaw, B., DeGusta, D., Gilbert, H., Richards, G. D., Suwa, G., \& Howell, F. C. (2003). Pleistocene Homo sapiens from Middle Awash, Ethiopia. Nature, 423 (6941), 742-747.

Woodward, J. C., \& Goldberg, P. (2001). The sedimentary records in Mediterranean rockshelters and caves: archives of environmental change. Geoarchaeology, 16(4), 327-354.

Wright, D. K., Thompson, J. C., Schilt, F., Cohen, A. S., Choi, J. H., Mercader, J., \& Welling, M. (2016). Approaches to Middle Stone Age landscape archaeology in tropical Africa. Journal of Archaeological Science.

Wurster, C. M., Munksgaard, N., Zwart, C., \& Bird, M. (2015). The biogeochemistry of insectivorous cave guano: a case study from insular Southeast Asia. Biogeochemistry, 124(1-3), 163-175.

Wurster, C. M., Bird, M. I., Bull, I. D., Creed, F., Bryant, C., Dungait, J. A., \& Paz, V. (2010). Forest contraction in north equatorial Southeast Asia during the Last Glacial Period. Proceedings of the National Academy of Sciences, 107(35), 15508-15511. 